\title{
ORDENAR AS PAIXÕES: RECONHECIMENTO E SOCIABILIDADE NO EMÍLIO DE ROUSSEAU - PRIMEIRA PARTE
}

\author{
Thomaz Kawauche ${ }^{1}$
}

\begin{abstract}
Resumo:
Este artigo examina em Emílio, ou Da educação o princípio da ordem das paixões como condição de sociabilidade. Pretende-se mostrar que, para Rousseau, "ordenar as paixões humanas" diz respeito não apenas a uma estratégia profilática retentora das paixões maléficas que necessariamente surgem junto com o amor-próprio ao longo do desenvolvimento de Emílio, mas também a uma tentativa para se compreender a relação entre moral e política do ponto de vista daquilo que hoje denominaríamos "teoria do reconhecimento". Trata-se aqui de expor a formulação do problema 'como ordenar as paixões ligadas ao amor-próprio?' no quadro da educação moral do jovem aluno, adotando como hipótese que a relação entre estima e consciência é o alicerce teórico sobre o qual Rousseau elabora um modelo de sociabilidade que leva em conta a ideia de reconhecimento.
\end{abstract}

Palavras-chave: Consciência. Educação. Medicina. Reconhecimento. Sociabilidade.

\section{TO ORDER THE PASSIONS: RECOGNITION AND SOCIABILITY IN ROUSSEAU'S EMILE - FIRST PART}

\begin{abstract}
:
This article examines in Émile, ou De l'Éducation the order of passions principle as condition of sociability. It is intended to show that, for Rousseau, "ordering human passions" is not just a prophylactic strategy that retains the evil passions that necessarily arise along with self-love throughout Emile's development, but also an attempt to understand the relationship between Morals and Politics from the point of view of what we would today call "Recognition Theory". This paper presents the formulation of the problem "how to order passions connected with self-love?' within the framework of the young disciple's moral education, assuming as hypothesis that the relationship between esteem and consciousness is the theoretical foundation on which Rousseau elaborates a model of sociability that takes into account the idea of recognition.
\end{abstract}

Keywords: Consciousness. Education. Medicine. Recognition. Sociability.

Um dos problemas considerados por Rousseau no quarto livro de Emílio, ou Da educação é o da gênese da sociabilidade. Na história do aluno que dá título à obra, estamos no momento da educação moral, ou mais especificamente, do estudo das relações humanas do ponto de vista das paixões. Com efeito, a exposição das mudanças ali sofridas por Emílio - o período de desenvolvimento corresponde à adolescência - recupera um tópico importante da ciência do homem no Discurso sobre a origem da desigualdade: a passagem do amor de si, paixão natural ligada à autoconservação e fonte primitiva das outras paixões, ao amor-

1 Doutor em Filosofia pela USP, Professor Visitante no Departamento de Filosofia da UNIFESP, membro fundador da Associação Brasileira de Estudos do Século XVIII (ABES XVIII) e autor do livro Religião e política em Rousseau: o conceito de religião civil (São Paulo: Humanitas \& FAPESP, 2013). E-mail: kawauche@unifesp.br 
próprio, paixão socialmente produzida caracterizada pela preferência de si mesmo na comparação com os demais indivíduos. A originalidade do quadro das paixões apresentado por Rousseau no Discurso, como todos devem saber, consiste em mostrar que o arco delineado do amor de si ao amor-próprio segue o seguinte esquema: (1) o progresso do espírito humano e o das instituições sociais são necessariamente entrelaçados entre si; (2) o entrelaçamento dos dois progressos engendra certas relações de dependência entre os agentes livres e, por conseguinte, transforma desigualdades físicas em desigualdades morais; (3) tais relações, submetidas a circunstâncias "funestas", produzem vícios que, por sua vez, produzem desigualdades morais cada vez mais graves e, por fim, os males consolidados acabam inviabilizando a própria ordem social.

Essa mesma forma de descrição da realidade reaparece no Emílio, porém, na perspectiva de uma "educação medicinal"2: no livro IV, o educador, à maneira de um médico hipocrático, intervém na história natural do amor-próprio recorrendo a remédios educativos adequados para cada situação patológica da vida de Emílio. A alegoria do jovem potencialmente misantropo que é curado da insociabilidade pela arte da educação não é gratuita: ela remonta à relação clássica entre medicina e paideia ${ }^{3}$ que Rousseau transpõe para os esquemas de inteligibilidade das ciências modernas. As intervenções correspondem às "cenas pedagógicas", das quais falaremos adiante. Por ora, basta entender que as "cenas" corrigem os eventuais desordenamentos no sistema de paixões de Emílio de forma similar à "arte médica da ocasião oportuna" (Souza, 2006, p. 251). Almeja-se assim, através dessa pedagogia terapêutica, a formação de um ser - homem ou cidadão - capaz de conviver em harmonia com os demais antes mesmo de atingir a idade adulta.

Pelo fato de estar baseado no modelo humoral da tradição hipocrática, os princípios educacionais de Rousseau podem ser tomados como uma terapia segundo o método expectante, com tratamentos voltados à economia das paixões, tanto na esfera do indivíduo quanto no âmbito da economia da ordem civil. (Vale lembrar que a palavra "oeconomie" pertence ao léxico da medicina, sendo "oeconomie animale" uma noção importantíssima na

\footnotetext{
2 A expressão "éducation médicinale des enfants" aparece no livro de Pierre Brouzet, Essai sur l'éducation médicinale des enfants et sur leurs maladies (1754). Trata-se de uma das fontes médicas que Rousseau utiliza para escrever o Emílio. Sobre esse assunto, ver Kawauche (2018).

3 Veja-se o capítulo “A medicina como paideia” em Jaeger (2001).
}

\begin{tabular}{|l|l|l|l|l|}
\hline Govista Qialectus & Ano 8 & n. 15 & Agosto - Dezembro 2019 & p. $328-361$ \\
\hline
\end{tabular}


estrutura de mentalidades entre os séculos XVI e XIX ${ }^{4}$.) Mais precisamente, se nos permitirmos terminologias anacrônicas, poderíamos falar até mesmo de uma pediatria, pois o pressuposto fundamental da arte da educação de Rousseau é que, embora a ordem da infância se inscreva no interior da ordem da humanidade, cada uma delas tem suas leis próprias, devendo portanto a ordem da criança ser regulada de maneira autônoma:

A humanidade tem seu lugar na ordem das coisas; a infância tem o seu na ordem da vida humana. É preciso considerar o homem no homem e a criança na criança; determinar para cada qual o seu lugar e ali fixá-lo, ordenar as paixões humanas de acordo com a constituição do homem [...]. (Rousseau, 1969, p. 303, meus os itálicos)

Como veremos, "ordenar as paixões humanas de acordo com a constituição do homem" significa, no contexto desta análise, efetivar a passagem saudável do amor de si para o amor-próprio. Antes de tudo, porém, nunca é demais repetir que, no Emílio, o amor-próprio não é um mal em si mesmo, mas, isto sim, efeito necessário do desenvolvimento da sociabilidade da criança ${ }^{5}$. Se, no Discurso, os aspectos nocivos desse desenvolvimento são pintados com cores mais chocantes (pois ali o mal não sofre tratamento), no Emílio, diferentemente, os traços negativos do amor-próprio ficam deslocados para um segundo plano de análise quando percebemos que, sem os progressos causados por essa paixão, Emílio não conseguiria se inserir de modo adequado na sociedade; por exemplo, ele seria incapaz de perceber qualquer tipo de vantagem em se associar com outros indivíduos movidos por interesses comuns. Ou seja, no Emílio, o amor-próprio é ambivalente à maneira de um mal necessário, semelhante ao pharmakon da medicina antiga, cujos efeitos colaterais podem até ser amenizados, mas não suprimidos: “O amor-próprio é um instrumento útil, mas perigoso; muitas vezes fere a mão que dele se serve, e raramente faz o bem sem o mal" (Rousseau, 1969, p. 536). De fato, ao descrever as transformações que vão do amor de si ao amorpróprio, Rousseau tem em vista duas faces desse processo, a uma só vez contraditórias e indissociáveis entre si: a face agregadora (podemos denominá-la assim), que diz respeito à produção de sentimentos de benevolência, comiseração, clemência, generosidade, etc., e a

4 Sobre a formação do conceito de "economia animal" no quadro de emergência da fisiologia enquanto ciência no século XVI, veja-se o seminal artigo de Bernard Balan: "Premières recherches sur l'origine et la formation du concept d'économie animale" (1975).

5 Convém observar que foi Nicholas Dent o primeiro comentador a chamar atenção para a ambivalência do amour-propre em Rousseau. Em seu livro Rousseau: An Introduction to his Psychological, Social and Political Theory, ele escreve: "Como veremos, Rousseau atribui ao amour-propre um papel essencial e totalmente benéfico para a plena autorrealização de qualquer pessoa na medida em que esta toma posse de sua posição enquanto 'ser moral' capaz de interagir com outros seres semelhantes. [...] É somente quando o amour-propre se torna desordenado ('inflamado') que Rousseau o critica como uma característica pessoal nociva e fonte de prejuízo social" (Dent, 1988, p. 4).

\begin{tabular}{|l|l|l|l|l|}
\hline Govista Dialectus & Ano 8 & n. 15 & Agosto - Dezembro 2019 & p. $328-361$ \\
\hline
\end{tabular}


face desagregadora (na falta de um termo melhor), ligada às paixões maléficas, como inveja, cobiça, vaidade, ódio, crueldade, desejo de vingança, etc.

Este trabalho é fruto de uma pesquisa em andamento sobre Rousseau e as ciências modernas. Apresento aqui algumas conclusões provisórias. O objeto de minha investigação é o princípio da ordem das paixões enquanto condição de sociabilidade na história de Emílio. Pretendo mostrar que, para Rousseau, “ordenar as paixões humanas” diz respeito não apenas a uma estratégia profilática retentora das paixões maléficas que necessariamente surgem junto com o amor-próprio ao longo do desenvolvimento do jovem aluno, mas também a uma tentativa para se compreender a relação entre moral e política do ponto de vista daquilo que hoje denominamos teoria do reconhecimento ${ }^{6}$. O texto é longo e, por isso, foi dividido em

6 Toda a bibliografia sobre teoria do reconhecimento em Rousseau gira em torno de Axel Honneth. É digno de nota que, no ensaio "Abismos do reconhecimento" (original publicado em 2012), Honneth chame Rousseau de "o fundador de toda a tradição da teoria do reconhecimento" (Honneth, 2013, p. 566). Como devemos saber, essa interpretação é fortemente inspirada por Frederick Neuhouser que, em Rousseau's Theodicy of Self-Love (2008), teoriza o reconhecimento em Rousseau à luz da tese da "teodiceia secular", a saber, que a crítica social rousseauniana apresenta um "potencial redentor do amor-próprio", porém, de um ponto de vista estritamente social, e não religioso. A despeito da validade da leitura de Neuhouser, seu mérito inegável é ter destacado o lugar do amor-próprio no modelo de sociedade de Rousseau em termos de uma teoria do reconhecimento puramente secular. Honneth marca sua posição relativamente à tese de Neuhouser enfatizando a importância de outras fontes passionais para a constituição civil, como o amor à glória e à pátria, e até mesmo à religião civil (Honneth, 2013, pp. 573-574). As conclusões de Honneth foram aprofundadas por Théophile Pénigaud de Mourgues (2014 e 2017), o qual afirma haver em Rousseau uma "política do reconhecimento" fundamentada num "desejo de reconhecimento", este associado à estima pública e, por conseguinte, ao amor-próprio. Embora suas análises passem pelo Contrato social, a referência principal de Pénigaud de Mourgues são as Considerações sobre o governo da Polônia, enfatizando assim o viés prático do pensamento político de Rousseau. Céline Spector desloca e amplia a discussão com Honneth ao tratar do reconhecimento em Rousseau na perspectiva de Charles Taylor: ela faz isso mediante a contraposição entre o ideal de autenticidade de Rousseau e o desejo de reconhecimento das comunidades contemporâneas segundo Taylor (Spector, 2014). Outra leitura crítica recente é a de Pierre Crétois (2017): fundamentado na ideia de Bruno Bernardi, para quem Rousseau é um "autocrítico das Luzes", Crétois problematiza a interpretação de Honneth afirmando que a teoria do reconhecimento de Rousseau não está limitada à ideia de alienação oriunda da teoria crítica frankfurtiana, mas que ela consiste numa análise social das diversas facetas do amor-próprio. Para um levantamento bibliográfico menos incompleto, seria preciso ainda mencionar o livro de Barbara Carnevali (Romantisme et reconnaissance: figures de la conscience chez Rousseau. Genebra: Droz, 2012), porém, não tive acesso a essa obra, infelizmente. No Brasil, o tema do reconhecimento no Emílio foi explorado por Cláudio Dalbosco em "Condição humana e formação virtuosa da vontade" (2014), cuja exposição articula, de um lado, a relação entre amor-próprio e reconhecimento nas leituras que F. Neuhouser e A. Honneth fazem de Rousseau e, de outro lado, uma hipótese acerca da "educabilidade do amor-próprio" do ponto de vista daquilo que Dalbosco denomina teoria (negativa e positiva) da virtude na doutrina pedagógica do Emílio. Convém lembrar que todos esses trabalhos remontam ao livro de Nicholas Dent, Rousseau: An Introduction to his Psychological, Social and Political Theory (1988), cuja originalidade está em ter sido o primeiro a relacionar os aspectos positivos do amor-próprio à ideia de reconhecimento. Com a intenção de oferecer um complemento aos trabalhos acima mencionados, apresento neste artigo uma interpretação que busca descrever, do ponto de vista das ciências modernas, a relação necessária entre a ideia de reconhecimento e a ordem das paixões - sobretudo a paixão do amorpróprio -, considerando-se a arte da educação como uma espécie de terapêutica moral. Em particular, tenho em vista os esquemas teóricos da medicina hipocrática utilizados por Rousseau para conceber o bom ordenamento passional do corpo político como condição de possibilidade para a vida civil, tanto no Emílio quanto no Contrato social. Trata-se aqui de lançar novas luzes sobre os conceitos de "reconhecimento" e "patologia social" com base na história do pensamento médico anterior ao advento da Psicanálise,

\begin{tabular}{|l|l|l|l|l|}
\hline Revista Cialectus & Ano 8 & n. 15 & Agosto - Dezembro 2019 & p. $328-361$ \\
\hline
\end{tabular}


duas partes. A primeira parte (este artigo) expõe a formulação do problema da ordem das paixões ligadas ao amor-próprio no quadro da educação moral de Emílio, adotando como hipótese que a relação entre estima e consciência é o alicerce teórico sobre o qual Rousseau elabora um modelo de sociabilidade que leva em conta a ideia de reconhecimento. $\mathrm{Na}$ segunda parte (em artigo a ser publicado), investigo os desdobramentos da relação entre estima e reconhecimento no interior do quadro teórico aqui exposto, dedicando atenção a dois pontos estruturantes do Emílio relativos ao ordenamento das paixões: (1) o modelo do espetáculo para as cenas pedagógicas e (2) a ideia de amizade para formação do juízo moral.

\section{As paixões e o empirismo: uma questão de medicina}

Comecemos com a leitura da passagem do livro IV em que Rousseau expõe as regras do método para o "uso das paixões". O trecho a seguir é digno de total atenção, pois em torno dele gira, não apenas a educação moral de Emílio enquanto adolescente, mas, de modo geral, todos os princípios da ciência do homem de nosso autor: "Eis, portanto, o sumário de toda a sabedoria humana quanto ao uso das paixões: 1. sentir as verdadeiras relações do homem, tanto da espécie quanto no indivíduo; 2. ordenar todos os afetos da alma conforme essas relações" (Rousseau, 1969, p. 501).

Em primeiro lugar, é fundamental aqui notar o aspecto empírico da doutrina pedagógica de Rousseau: em vez de investigar a origem das paixões ou buscar suas causas finais, o educador deve fazer bom uso delas, ou ainda, buscar sua utilidade de um ponto de vista prático, considerando-as tais como aparecem na experiência e empregando-as de modo proveitoso na formação do aluno em observação ${ }^{7}$. E, mais do que empíricas, são regras que recusam idealizações racionais, pois, longe de enunciar um programa de combate às paixões, trata-se de valer-se delas mesmas para produzir laços sociais com base nas relações de dependência entre indivíduos egoístas: "Só se conquista as paixões pelas paixões; é por meio do império delas que precisamos combater-lhes a tirania, e é sempre da própria natureza que é preciso tirar os instrumentos próprios para regulá-la” (Rousseau, 1969, p. 654). Tal máxima se coaduna perfeitamente com o princípio hipocrático de extrair da doença seu próprio remédio, que Jean Starobinski (2001) generaliza para o pensamento de Rousseau como um todo.

valorizando assim a originalidade da crítica social de J.-J. Rousseau e evitando confusões semânticas com a teoria crítica de A. Honneth.

7 Sobre a importância dos conhecimentos úteis para a formação da autonomia no Emílio, ver a tese de Terezinha Duarte Vieira (2017).

\begin{tabular}{|c|c|c|c|}
\hline Qovista Dialectus & \begin{tabular}{|l|l|} 
Ano 8 & n. 15 \\
\end{tabular} & Agosto - Dezembro 2019 & p. $328-361$ \\
\hline
\end{tabular}


Segundo o autor do Emílio, é preciso encarar as paixões como instrumentos necessários à conservação do ser humano, tanto do ponto de vista do indivíduo quanto do ponto de vista da espécie, tendo-se, todavia, o cuidado de não menosprezar os vícios inerentes às transformações do amor de si em amor-próprio. No léxico rousseauniano, a palavra que designa tal uso regulado das paixões é ordenação; assim como ocorre na constituição do corpo político no Contrato social (livro I, cap. 6), não se trata de criar novas forças, mas de ordenar as que já existem, uni-las a fim de fazê-las "agir em concerto" (Rousseau, 1964b, p. 360); no tocante à divisão das leis, o Contrato (livro II, cap. 12) também recorre à ideia de relações ordenadas entre partes constituintes do corpo político, notadamente a conflituosa relação envolvendo o governo e o soberano: "Para ordenar o todo ou dar a melhor forma possível à coisa pública, há que considerar diversas relações” (Rousseau, 1964b, p. 393). Comparando assim o léxico imanentista do Contrato e do Emílio, identificamos um campo semântico envolvendo a ordem do corpo social e a ordem do corpo da criança de acordo com os princípios gerais da antiga tradição do empirismo médico ${ }^{8}$ : sem perder tempo com hipóteses acerca da essência do homem ou de seu telos, o educador de Emílio se restringe a ordenar as configurações patológicas adotando como parâmetros, por um lado, os casos compilados da história natural das paixões humanas, e por outro lado, a harmonia das faculdades e dos órgãos sensíveis do aluno; de modo análogo, na perspectiva das relações sociais, a arte do Legislador, que pode ser visto como um "pedagogo dos povos" (Burgelin, 1962, p. 56), consiste em ordenar a constituição dos homens considerando-os tais como são na realidade observada, e não como deveriam ser idealmente, buscando-se na prática um ajuste conveniente dos móbiles passionais que engendram, para o bem ou para o mal, as instituições sobre as quais se sustenta a constituição civil.

A palavra constituição, que podemos entender como sinônimo de ordem, vem também da medicina: veja-se, por exemplo, os verbetes "Catastasis" e "Constitutio" do Dictionnaire universel de médecine traduzido do inglês por Diderot. Sua origem remonta ao Corpus Hippocraticum; o termo em grego, katastasis, aparece, por exemplo, no livro I das Epidemias, referindo-se não apenas ao corpo do ser vivente, mas também ao seu entorno, isto é, ao ambiente em que se situa. É lugar-comum falar-se da influência dos climas sobre a saúde. Com efeito, é o exame semiológico da constituição que leva o médico ao diagnóstico das doenças de seu paciente, donde se chega à ideia de saúde como sinônimo de boa ordem da

8 Sobre a importância do empirismo médico nos quadros conceituais dos séculos XVII e XVIII, veja-se especialmente Duchesneau (1973) e Salomon-Bayet (2008).

\begin{tabular}{|l|l|l|l|l|}
\hline Qovista Dialectus & Ano 8 & n. 15 & Agosto-Dezembro 2019 & p. $328-361$ \\
\hline
\end{tabular}


constituição. Outro escrito hipocrático relevante desse ponto de vista é Ares, águas e lugares, que fornece um modelo clássico de relação entre katastasis e comportamento humano: o lugar-comum, nesse caso, é falar-se da influência do meio físico sobre a moral. Filósofos como Montaigne, Montesquieu e Rousseau apreciavam Ares, águas e lugares porque essa obra os inspirava nas reflexões acerca da saúde moral do indivíduo a partir de quadros clínicos da ordem civil. Mutatis mutandis, a expressão "patologias do social", utilizada por Axel Honneth (2011, 2013 e 2014) em sua teoria crítica, não seria descabida para os referidos autores da modernidade. Vale notar que, no Discurso sobre a desigualdade, Rousseau compara a história das doenças humanas e a história das sociedades civis tomando como referência a analogia entre o comportamento pouco saudável dos habitantes das cidades e a "boa constituição dos selvagens" (Rousseau, 1964a, p. 138). No caso do Emílio, as expressões "ordem da infância", "ordem da natureza" e "ordem civil" são correlatas, pois todas dizem respeito à constituição do educando. Nesse quadro, interessa-nos apenas o plano do livro IV, onde a constituição estabelecida pelo bom uso das paixões se distingue da ordem da primeira infância: se até então o conhecimento de Emílio era formado com base na coincidência entre o "mundo real" e o "mundo imaginário", desse momento em diante haverá um descolamento controlado dos objetos da imaginação relativamente aos objetos sensíveis. Isso significa que, por intermédio de uma expansão dos limites do saber abstrato frente à realidade das coisas, a formação do conhecimento moral deverá necessariamente apartar-se da constituição da ordem sensível e encontrar seu próprio território de jurisdição - este, como veremos, será empiricamente delimitado pelo critério regulador das "relações do homem", que tende a ser

9 A definição de "patologia", no contexto da teoria de Axel Honneth, é "qualquer desenvolvimento social que prejudica a habilidade de participar racionalmente em importantes formas de cooperação social", com sentido de "maus desenvolvimentos ou desordens" (Honneth, 2014, p. 86). Ou seja, se há patologia social numa determinada sociedade, os membros desse corpo político doente, por assim dizer, deixam de agir de modo saudável, pois, pelas determinações da própria ordem (ou desordem) civil, eles só conseguem agir de modo a fomentar ainda mais as patologias existentes, e isso, a despeito da consciência que possuam de seus atos. Um exemplo que me parece sintomático nas sociedades pré-capitalistas é o desenvolvimento do amor pelo dinheiro por parte de agentes livres, cujo diagnóstico vemos na crítica à ideia de representação política no Contrato social. Segundo Rousseau, o dinheiro (e a desigualdade de posses de modo geral) introjeta na moral dos cidadãos o assentimento de valores que reconhecem os bens materiais como sinônimo de virtude, tornando-se assim aceitável que as relações de mercado condicionem as relações civis, como quando alguém paga a outrem para ser seu representante no campo da política, o que, na definição de Honneth, corresponde a um mau desenvolvimento (ou desordem) do corpo político. No quadro clínico de Rousseau, a patologia do dinheiro ameaça a saúde do soberano, pois engendra comportamentos de seus membros que necessariamente tendem a agravar a causa próxima da desordem, com efeitos irreversíveis. O amor ao dinheiro, como lemos no cap. 15 do livro III, se manifesta no indivíduo quando este assente que, não apenas a ação virtuosa pode ser representada, mas também que essa representação pode ser paga com dinheiro: “A palavra Finança é uma palavra de escravo; é desconhecida na Cidade. Num Estado realmente livre, os cidadãos fazem tudo com seus braços, e nada com o dinheiro. Longe de pagar para isentar-se de seus deveres, pagariam para cumpri-los eles mesmos" (Rousseau, 1964b, p. 429).

\begin{tabular}{|c|c|c|c|c|}
\hline Qovista Dialectus & Ano 8 & n. 15 & Agosto - Dezembro 2019 & p. $328-361$ \\
\hline
\end{tabular}


melhor ou pior na medida em que a "gestão das paixões"10 tornar mais ou menos possível o equilíbrio entre a "ordem das coisas" e a "ordem da vida humana". Com base no que vimos acerca das palavras constituição e ordenação, examinemos agora o que Rousseau quer dizer com "as verdadeiras relações do homem".

\section{A estima como embrião do juízo moral e as "verdadeiras relações" como meio}

Quanto àquilo que antecede o "segundo nascimento", não se trata mais das puras "relações das coisas" concernentes aos sentidos físicos: aos quinze anos, Emílio começa a comparar impressões causadas por objetos morais (por exemplo, verdades que correspondem a diferentes graus de assentimento interior), e a palavra empregada para designar esse novo recurso do espírito é estima. Embora Rousseau não defina o substantivo "estime" nem o verbo "estimer", podemos inferir sua ideia básica na descrição do juízo rudimentar negativo do bebê quando este passa pelas mãos de diversas amas-de-leite, o que coloca em questão nada menos que os efeitos do desenvolvimento ultraprecoce do amor-próprio: "A cada mudança [de amade-leite] ela [a criança] faz secretas comparações que tendem sempre a diminuir sua estima por aqueles que a governam" (Rousseau, 1969, p. 274). O sentimento da estima, que podemos compreender como embrião do juízo moral, se desenvolve pelo exercício habitual das comparações. Essa nova tecnologia do espírito, por assim dizer, será conforme à ordem das coisas $^{11}$ - e, por conseguinte, também à ordem da natureza - se puder se manifestar como uma estima natural, ou seja, como um movimento do espírito que emerge de comparações aprovadas pelo assentimento interior com o mínimo de intermediação da faculdade racional ${ }^{12}$.

10 É bastante apropriada a ideia de "gerir as paixões" discutida por Michel Delon no quadro da fisiologia vitalista do final do século XVIII. Naquele contexto, tanto moralistas quanto médicos pensam com base no esquema de inteligibilidade que relaciona "gestão das paixões" e "harmonia interior", buscando soluções nas vias terapêuticas, em particular, a administração das "energias" do organismo vivo segundo o modelo da boa ordem do corpo saudável, o que via de regra era concebido por analogia no modelo da "economia" do corpo político: "a vida moral é pensada ao modo da economia" (cf. Delon, 1988, p. 356). Infelizmente, não há espaço para entrarmos na discussão sobre medicina e economia no Emílio de Rousseau. Neste artigo, limitome a falar do equilíbrio que diz respeito aos efeitos sociais da boa "gestão das paixões".

11 Deve-se notar o sentido muito preciso que Rousseau atribui à expressão "ordre des choses" quando esta aparece ao lado de "nature": a ideia de um ordenamento "das coisas" diz respeito a um dado natural modificado pela arte humana. O sentido é inferido da distinção das "três educações" no primeiro livro do Emílio (cf. Rousseau, 1969, p. 247): a educação da natureza (ordem com relação à qual nada podemos fazer, p.ex., o processo de crescimento da criança), a educação dos homens (ordem artificial de tudo aquilo criado pela arte humana, p.ex., os usos e costumes), e a educação das coisas (ordem intermediária entre as outras duas, como uma interface entre a ordem natural e a ordem artificial, p.ex., o corpo do bebê deformado pelo hábito de enfaixá-lo em cueiros).

12 Rousseau fala do "sentimento inato de justiça" na Profissão de fé. Trato da relação entre sentimento interior e sentimento inato de justiça no artigo "Consciência e sentimento no Emílio de Rousseau", que espero publicar em breve.

\begin{tabular}{|c|c|c|c|}
\hline Ronista Dialectus & \begin{tabular}{l|l} 
Ano 8 & n. 15
\end{tabular} & Agosto - Dezembro 2019 & p. $328-361$ \\
\hline
\end{tabular}


Daí dizermos que, nos progressos de Emílio, a estima natural se encontra a meio-caminho entre o amor de si mesmo (livros I e II) e o juízo moral (livros IV e V). Obviamente, em caso de fracasso da arte do educador, a estima passará a se manifestar negativamente, pois embora não deixe de engendrar laços de sociabilidade, tenderá a produzir, com ajuda das circunstâncias desfavoráveis, elementos passionais de desagregação social. Etapa importante nessa arriscada aventura é a lição de "economia", quando o educador trata da divisão do trabalho mediante a comparação entre artes mecânicas e artes de indústria (livro III); nesse estágio intermediário entre o físico e o moral, Emílio conhecerá a tentadora "estima pública" na oficina de marcenaria onde, ao participar pela primeira vez do trabalho humano, aprenderá que existem necessidades que ultrapassam as capacidades físicas do indivíduo, e que por isso a cooperação é indispensável para a sobrevivência. Na transição do livro III para o IV, Emílio inferirá que essas relações de cooperação imediatas podem ser generalizadas para toda a sociedade, e assim, tornar-se-á finalmente apto para estimar as "grandes relações" da ordem civil $^{13}$. O preço desse aprendizado perigoso é que a estima e o amor-próprio são inseparáveis, de tal maneira que Emílio ficará necessariamente mais vulnerável aos efeitos funestos dessa paixão, por exemplo, quando o cooperativismo deixar de ser equitativo e as relações de dependência nocivas começarem a infectá-lo. De todo modo, o educador deve atuar como um médico higienista ${ }^{14} \mathrm{e}$, a todo custo, manter Emílio longe das relações que engendram vícios relações como aquelas que hoje conhecemos como relações de exploração da mão de obra, nas quais o amor-próprio se manifesta perversamente tanto na constituição dos dominadores (o mestre-artesão se reconhece como senhor de seus funcionários) quanto na dos explorados (os trabalhadores disputam entre si a preferência do senhor na busca do prêmio de serem

13 Veja-se que, do ponto de vista da formação do juízo, a relação de dependência que surge com o trabalho cooperativo não é ruim, pois a posição que Emílio ocupa na cadeia das artes e dos ofícios é a do justo meio entre as artes mecânicas (pouco estimulantes para o progresso do espírito) e as artes liberais (excessivamente estimulantes para o amor-próprio, e portanto, nocivas). Além disso, Rousseau toma o cuidado de eliminar nessa "cena" o elemento viciante do olhar do outro sobre a arte produzida, assegurando assim um bloqueio do progresso da vaidade. Daí o sentido da escolha da marcenaria como a melhor profissão para Emílio, pois os móveis de madeira, longe de serem comparáveis às obras de artistas vaidosos, são peças que não chamam atenção, pois restringem-se à mera utilidade do cotidiano. A obra do marceneiro se distingue tanto do trabalho grosseiro do lenhador, que providencia a matéria bruta da fabricação dos móveis, quanto do trabalho excessivamente refinado do ebanista, que vê os móveis de madeira como obras de arte dignas de apreciação estética. A imagem evocada por Rousseau para as atividades desse momento é a do personagem do romance de Defoe: "um ofício que pudesse servir a Robinson em sua ilha" (Rousseau, 1969, p. 474); ou seja, a "cena" da marcenaria é uma primeira exposição de Emílio ao meio social, porém, tendo-se garantida na ordem das paixões a imunidade contra os males sociais da dependência e da vaidade.

14 O campo semântico da medicina e da moral se sobrepõem quando "higiene" e "temperança" convergem no sentido de uma via média ou um justo meio, o que se verifica no livro I do Emílio: "A única parte útil da medicina é a higiene, e mesmo assim a higiene é menos uma ciência do que uma virtude. A temperança e o trabalho são os dois verdadeiros médicos do homem: o trabalho aguça seu apetite e a temperança impede que abuse dela" (Rousseau, 1969, p. 271). Curiosamente, nesse trecho fala-se de trabalho.

\begin{tabular}{|c|c|c|c|c|}
\hline Qovista Dialectus & Ano 8 & n. 15 & Agosto - Dezembro 2019 & p. $328-361$ \\
\hline
\end{tabular}


reconhecidos como bons escravos). As "verdadeiras relações" são relações de equidade e dizem respeito à ideia de justiça política na teoria contratualista de Rousseau ${ }^{15}$. Na alegoria médica, podemos dizer que as "verdadeiras relações do homem" poupam Emílio de efeitos colaterais mais graves porque funcionam como meio ${ }^{16}$ adequado para o desenvolvimento saudável do amor-próprio, algo como um tecido social constituído por ligações pautadas pelo princípio da isonomia.

Grosso modo, o que Rousseau tem em mente ao falar de estima nesse momento é um ato da consciência operado a partir de comparações bem simples e pouco dependentes da razão. Aos quinze anos, "já comparou ideias demais para nada sentir, mas não o bastante para conceber o que sente" (Rousseau, 1969, p. 505). Na prática, a estima se manifesta originalmente como um reconhecimento sensível do eu de Emílio perante outros seres sensíveis: "O primeiro sentimento de uma criança é amar a si mesma; o segundo, que deriva do primeiro, é amar aos que dela se aproximam, pois, no estado de fraqueza em que se encontra, ela não conhece ninguém a não ser pela assistência e pelos cuidados que recebe" (Rousseau, 1969, p. 492). Na idade adulta, quando tais comparações puderem ser efetivadas com mais elaboração racional, ou, como diria Rousseau, com mais atividade do espírito, elas passarão a ser denominadas juízos morais, o que, na démarche do livro IV, acontecerá na Profissão de fé do vigário saboiano, mais especificamente, na longa e complexa exposição da ideia de consciência. Convém lembrar que esse atraso no desenvolvimento da razão é proposital no Emílio, uma vez que, para Rousseau, o progresso precoce da capacidade de raciocínio é uma das fontes de corrupção da economia do amor-próprio.

Ora, não é preciso ser kantiano para afirmar que a estima bem cultivada fornece ao jovem condições de tornar-se um adulto com juízo autônomo capaz de discernir corretamente, pela razão prática, o bem e o mal em meio à sociedade. Entre a bondade natural do bebê e a corrupção dos adultos, os primeiros cuidados com a estima natural são de máxima importância, pois estamos falando de um ponto de inflexão na história hipotética do

15 No Contrato social, isso pode ser exposto mediante uma análise dos capítulos 6 e 7 do livro II, tendo-se em vista a relação entre a lei e o legislador. No capítulo 3 de meu livro (cf. Kawauche, 2013), demonstro que o legislador estabelece as verdadeiras relações entre os homens para que a vontade geral possa ser expressa pelo povo soberano em forma de leis, muito embora eu não tenha me referido ali explicitamente a uma 'teoria da justiça' em Rousseau.

16 Utilizo aqui o termo "meio" no sentido sugerido por Georges Canguilhem, a saber, um sistema de relações cuja estrutura é constituída pela interação entre o organismo e seu entorno (cf. Canguilhem, 2012, no capítulo "O vivente e seu meio"). Da maneira como exponho neste artigo, o sentido é o mesmo de "constituição". Sobre o princípio da isonomia do ponto de vista médico, ver meu artigo "Emílio e a medicina antiga" (Kawauche, 2017). 
desenvolvimento das paixões de Emílio: é quando o jovem ainda não foi infectado pela heteronomia da opinião pública e, exatamente por isso, goza de meios favoráveis para aprender a julgar os outros segundo a natureza na medida em que for capaz de estimá-los em relação a si mesmo. Emílio ainda não reflete como um adulto, mas, em compensação, é bem atento à voz natureza devido à própria curiosidade infantil; a criança curiosa tem a sensibilidade aguda e, por conseguinte, mesmo sem a razão desenvolvida, é capaz de fazer comparações simples:

Que saiba que o homem é naturalmente bom, que ele o sinta, e que julgue o próximo por si mesmo; mas que veja como a sociedade deprava e perverte os homens; que encontre nos preconceitos deles a fonte de todos os seus vícios; que seja levado a estimar cada indivíduo, mas que despreze a multidão [...]. (Rousseau, 1969, p. 525)

A expressão "julgar o próximo por si mesmo" significa tomar a si mesmo como referência para medir a alteridade moral, ou, dito de outro modo, significa desconsiderar a opinião alheia como parâmetro do juízo no julgamento de outrem. Essa autofundamentação do juízo nos remete ao homem primitivo do Discurso sobre a desigualdade: há no estado de natureza um momento em que, embora o ser humano já seja capaz de estabelecer certas relações simples por meio de comparações, estas são realizadas menos por um ato reflexivo do que por "prudência maquinal", uma vez que nesse estágio o homem julga apenas "quando necessário e quase sem pensar" (Rousseau, 1964a, p. 165). No momento em que se encontra Emílio, seu coração ainda não foi afetado pelos preconceitos da sociedade, permanecendo portanto puro; assim, o jovem aluno pode considerar a própria opinião como a voz da natureza a despeito de seus interesses particulares latentes. Poderíamos dizer que seu egoísmo ainda é perdoável ou que seus interesses particulares ainda não produzem efeitos significativos nas relações sociais. Quanto à multidão, esta deve ser desprezada, o que, como Honneth (2011) nos ensina, não deixa de ser uma forma de reconhecimento: vemos aí nada menos do que uma "sociedade do desprezo". Apenas a título de esclarecimento, convém notar que, no trecho citado, o desprezo à multidão não é uma recomendação absoluta, pois em outra passagem Rousseau admite a possibilidade de se conhecer o coração do homem observando-o em meio à multidão (cf. Rousseau, 1969, p. 530). De fato, no livro quinto, quando seu juízo moral estiver plenamente desenvolvido, Emílio vai viajar sozinho durante dois anos a fim de observar e julgar as multidões dos povos ao redor do mundo. Nesses termos, se nossa pretensão for a de realizar uma leitura sistemática da teoria pedagógica do escritor genebrino, o repúdio às multidões na passagem acima deve ser contextualizado junto às cenas do livro III e com base apenas na oposição entre estima natural e estima pública, a primeira ligada ao 
sentimento interno e à voz da natureza, e a segunda concernente às opiniões e aos preconceitos, como no caso das artes de indústria. No fundo, pode-se entender que, com maior ou menor perigo, as "verdadeiras relações" encontram-se sempre no meio da multidão.

\section{O sentimento de estima entre a natureza e a opinião pública}

Frente a essa espécie de limbo que é a fronteira entre a infância e a puberdade, Rousseau busca abrir uma clareira para localizar o sentimento de estima natural. Ele tenta localizar, na transição para a ordem moral, o instante imediatamente anterior àquele em que o sentimento interno se corrompe e passa a se manifestar como estima pública. No progresso das paixões, tanto em Emílio quanto no Discurso sobre a desigualdade, isso se dá quando o indivíduo deixa de julgar o próximo por si mesmo e passa a julgar de acordo com as opiniões dos outros. Um primeiro exame dessa transição aparece no livro III, quando Rousseau trata da divisão do trabalho na oficina de marcenaria: Emílio precisa fabricar móveis que, quando apreciados pela sociedade, sejam considerados não apenas úteis, mas também belos: "a elegância e o gosto não se excluem da forma das obras que a utilidade determina" (Rousseau, 1969, p. 478). Nossa primeira dúvida é, portanto, se ele sucumbirá às tentações do mundo humano.

Contudo, a questão é bem mais complexa do que isso e a lição da marcenaria deve ser lida no contexto de outra maior: a lição que ensina Emílio a preferir o bom gosto dos pobres ao bom gosto dos ricos. O pano de fundo dessa longa cena pedagógica consiste em duas reflexões em torno à ideia de "rang", termo que diz respeito à posição hierárquica de alguém na sociedade do Antigo Regime e que não deve ser confundido com "classe" no sentido de camada da estrutura econômica da sociedade ${ }^{17}$ : no livro III do Emílio, a primeira

17 Eis uma passagem exemplar onde Rousseau compara "rang" e "état" (duas palavras próximas do ponto de vista semântico) para mostrar que, na transição da ordem física para a ordem moral, a preservação da vida deve continuar a ser mais importante que a manutenção da condição social: "Assim que Emílio souber o que é a vida, meu primeiro cuidado será ensiná-lo a conservá-la. Até aqui, não distingui as condições, as posições [rangs], as fortunas; e não as distinguirei daqui em diante porque o homem é o mesmo em qualquer condição [état]; o rico não tem o estômago maior do que o pobre e não digere melhor do que ele; o senhor não tem braços mais longos nem mais fortes do que seu escravo; um grande não é maior do que um homem do povo; e, enfim, sendo as necessidades naturais as mesmas em toda parte, iguais em toda parte devem ser os meios de satisfazê-las" (Rousseau, 1969, p. 468). Se houvesse espaço neste artigo, poderíamos desdobrar a seguinte hipótese para interpretar a teoria do reconhecimento de Rousseau: a patologia social do Discurso sobre a desigualdade pode ser diagnosticada à luz do argumento segundo o qual os homens trabalham para sua própria vergonha; nessa análise, falaríamos algo acerca dos dispositivos de reconhecimento na relação entre ricos e pobres tais como aparecem no Discurso. Rousseau é claro quando descreve que a patologia da desigualdade de "rangs" ou "états" produz comportamentos tanto de ricos (habituam-se a dominar e usurpar) quanto de pobres (habituam-se servir e a pilhar), tendo como resultando dessa história natural um "terrível

\begin{tabular}{|l|l|l|l|l|}
\hline Rovista Cialectus & Ano 8 & n. 15 & Agosto - Dezembro 2019 & p. $328-361$ \\
\hline
\end{tabular}


dessas reflexões é a que faz o aluno comparar um almoço opulento a um almoço simples e rústico (Rousseau, 1969, pp. 463-465); a segunda, no final do livro IV, consiste numa série de considerações acerca de uma hipótese, a saber, o que Emílio faria se fosse rico? (Rousseau, 1969, pp. 678-691). Emílio acaba concluindo que a riqueza vale menos pelas conveniências da vida luxuosa das cortes do que pelo gozo material que pode experimentar na vida simples do campo, além de constatar em seu próprio corpo que tanto os jantares mais luxuosos quanto aqueles mais simples serão necessariamente evacuados, com a diferença de não haver sofrimento devido a injustiças sociais na produção dos jantares mais simples (note-se aí a relação entre piedade e reconhecimento):

Com um julgamento sadio, que nada pôde corromper, que pensará do luxo, quando verificar que todas as regiões do mundo contribuíram naquilo, que vinte milhões de mãos trabalharam, talvez durante muito tempo, que isso talvez custou a vida de milhares de homens, e tudo para apresentarlhe pomposamente ao meio-dia o que à noite vai depositar em seu banheiro? (Rousseau, 1969, p. 463)

Nessa mesma perspectiva, Emílio reflete que, "se fosse rico, [...] eu seria sensual e voluptuoso mais do que orgulhoso e vão, e que me entregaria ao luxo da indolência mais do que ao luxo de ostentação" (Rousseau, 1969, p. 678). A cena do ateliê de marcenaria aparece, pois, entre esses dois momentos de reflexão, e o ensinamento no contexto consiste em afirmar que a estima pública deve se direcionar para o ganho de liberdade, e não para o ganho de riquezas materiais, pois importa mais o prazer de ser homem do que ser rico. (Note-se que a palavra "volúpia" tem muito peso nesse contexto, pois ela diz respeito a uma ordem das paixões em que a satisfação imediata vale mais do que o cálculo do homo economicus que anela pelos luxos futuros.) Essa máxima encontra-se resumida numa passagem ao final do livro IV: “O único laço de minhas relações seria o apego mútuo, a conformidade dos gostos, a conveniência dos caracteres; eu me conduziria como homem, e não como rico" (Rousseau, 1969, p. 683, meus os itálicos). E o mais importante de todo esse comentário é notar que a autodeterminação do comportamento de Emílio é fundamentada no reconhecimento da diferença socialmente construída entre ricos e pobres: “Os homens não são naturalmente nem reis, nem grandes, nem cortesãos, nem ricos; todos nascem nus e pobres, todos sujeitos às

estado de guerra": o "gênero humano [...] não podendo voltar atrás nem renunciar às infelizes aquisições que fizera e trabalhando apenas para a sua vergonha, pelo abuso das faculdades que o dignificam, colocou a si mesmo às portas de sua ruína" (Rousseau, 1964a, pp. 175-176, meus os itálicos). Na chave da metáfora médica, podemos falar em termos etiológicos, recorrendo para tanto ao caso da neoplasia (p.ex., um câncer de pele), cujo progresso ocorre imperceptivelmente devido a maus hábitos de vida (p.ex., caminhar habitualmente sob sol forte), numa combinação de necessidade e liberdade que, ao fim e ao cabo, se expressa na forma de uma história natural de patologia social. O título do artigo poderia ser: "A desigualdade econômica como neoplasia social".

\begin{tabular}{|c|c|c|c|c|}
\hline Qonista Dialectus & Ano 8 & n. 15 & Agosto - Dezembro 2019 & p. $328-361$ \\
\hline
\end{tabular}


misérias da vida, às tristezas, aos males, às necessidades, às dores de toda espécie" (Rousseau, 1969, p. 504). Com efeito, a distinção entre o homem e o homem rico é de suma importância, pois é com base nela que, do ponto de vista moral, a estima tornar-se-á imune à sedução da riqueza e, assim, poderá reconhecer entre os homens suas "verdadeiras relações" a despeito da desigualdade econômica implicada nos indivíduos em comparação.

Outra dúvida que surge diante dessa maneira de se conceber o ordenamento das paixões é: como assegurar que o reconhecimento das verdadeiras relações seja efetivo, e não apenas uma possibilidade deveras improvável? Ora, Rousseau enfrenta essa questão apostando na necessidade da analogia entre as leis físicas (dentre as quais, as leis da fisiologia do organismo humano) e as leis morais. No Emílio, essa questão aparece no importantíssimo princípio da "liberdade bem regrada" (Rousseau, 1969, p. 321). Com efeito, é graças à ideia de uma lei da liberdade que Rousseau pode pensar no reconhecimento como um fenômeno necessário. Dessa forma, a necessidade do reconhecimento é um fato empírico tão plausível quanto a necessidade de fenômenos físicos como o movimento dos corpos celestes. Algo que Montesquieu tornara plausível do ponto de vista dos empiristas no Espírito das leis, onde fica demonstrado que a infinita diversidade das instituições humanas pode ser conhecida através de princípios extraídos da natureza das coisas, como numa cadeia de verdades inferida mediante raciocínios rigorosamente empiristas. Segundo Montesquieu (1974, p. 33), as leis se definem como "relações necessárias que derivam da natureza das coisas" tanto no mundo material quanto no mundo humano, o que, na perspectiva da história da filosofia, podemos entender como um esforço teórico para conciliar necessidade e liberdade no quadro de um sistema de pensamento.

Outra autoridade citada pelos filósofos para provar a plausibilidade de se comparar leis físicas e leis morais é Locke. No Discurso Preliminar da Encyclopédie, d'Alembert escreve: Locke "reduziu a Metafísica ao que ela deve ser de fato, uma Física experimental da alma, espécie de Física muito diferente daquela dos corpos, não somente por seu objeto como também pela maneira de considerá-lo" (Diderot \& D'Alembert, 2015, p. 177). Nesse sentido, o Ensaio sobre o entendimento humano consistiria numa ciência da alma cujos princípios seriam expostos segundo a linguagem da doutrina empirista. O problema é filosoficamente complexo e, para os propósitos deste artigo, dele só nos interessa o paralelismo entre a necessidade das leis (morais e físicas) e a necessidade das relações (morais e físicas) que representam as leis. A fim de compreendermos essa correspondência num quadro mais próximo ao do Emílio, devemos comentar uma expressão empírica da ideia 
de "sentimento" que os filósofos do século XVIII consideravam tão plausível e representável quanto as causas eficientes nos modelos da física newtoniana: os atos da consciência.

\section{Sentir o outro à maneira de Newton: da piedade à consciência}

A grandeza de Rousseau no Emílio está no empenho para se imaginar as relações sociais com base numa física da moral, inspirada em parte no modelo da "Civil Science" de Hobbes, mas também nas ideias newtonianas e lockianas que eram aceitas no senso comum dos filósofos. A ciência da moral no Emílio considera, a uma só vez, os mecanismos da consciência do indivíduo (à maneira de Locke) e a rede de relações intersubjetivas numa trama onde a urdidura do liame social vem das conexões entre consciências; estas se reconhecem umas às outras e são atraídas umas em direção às outras por sentimentos qualificados, ora como naturais, ora como morais. É desse amálgama envolvendo natureza e artifício que se trata sempre que Rousseau se refere a sentimentos relativos - e de modo geral sempre que utiliza a palavra "sentimento" - no quadro das paixões humanas.

A ideia de sentimentos puramente naturais, como devemos saber, não é nova: o modelo emblemático no âmbito do empirismo moderno encontra-se no Tratado da natureza humana (II, i, 11); ali Hume descreve a simpatia (sympathy) como sentimento natural que, nas relações entre indivíduos, permite o reconhecimento de paixões e sentimentos semelhantes: Hume fala numa "propensão a simpatizar com os outros e a receber por comunicação suas inclinações e sentimentos, por mais diferentes e até contrários aos nossos" (Hume, 2009, p. 351). Se nossa abordagem fosse exaustiva, teríamos que entrar no debate médico sobre a simpatia; e a propósito, valeria a pena comentar a tese de Andrew Cunningham (1999), que interpreta os modelos iatromecânicos do holandês Herman Boerhaave e do escocês Robert Whytt como prováveis fontes que inspiram a teoria da simpatia em Hume. Todavia, esse desvio pelas leituras de Hume e de seus intérpretes exigiria análises de fôlego, e até mesmo uma análise superficial extrapolaria o escopo deste artigo. Portanto, limitar-nos-emos ao pensamento de Rousseau.

No Emílio, o sentimento natural mais próximo da simpatia de Hume é a piedade (pitié): esta encontra-se no momento primitivo da sociabilidade e, por isso mesmo, opera no terreno das relações de reconhecimento segundo a natureza, sendo definida pelo próprio Rousseau como "primeiro sentimento relativo que toca o coração humano segundo a ordem da natureza" (Rousseau, 1969, p. 505). Os sentimentos do bebê também entram no mesmo

\begin{tabular}{|c|c|c|c|}
\hline Qenista Dialectus & \begin{tabular}{|l|l|} 
Ano 8 & n. 15 \\
\end{tabular} & Agosto - Dezembro 2019 & p. $328-361$ \\
\hline
\end{tabular}


registro da piedade, pois levam a reconhecimentos naturais: alguns parágrafos atrás vimos que, para a criança, o primeiro desdobramento do amor de si mesmo consiste em "amar aos que dela se aproximam” (Rousseau, 1969, p. 492), ou seja, o primeiro ato de reconhecimento do bebê é um misto de piedade e apego que, a despeito de sua faceta social, ainda se manifesta no âmbito dos sentimentos naturais.

Todavia, do ponto de vista das "relações do homem" no livro IV do Emílio, não se trata apenas de piedade, pois não estamos falando de sentimentos estritamente naturais: a piedade entra no emaranhado de relações que, misturando o natural e o moral na constituição civil, servem de substrato para a formação dos "sentimentos de sociabilidade"18. A confluência entre os efeitos da piedade e as primeiras manifestações de sociabilidade nos leva à hipótese de uma teoria do reconhecimento dos afetos primitivos (leia-se aí: de afetos que ainda não foram contaminados de modo irreversível pelos costumes em sociedade ${ }^{19}$ ); teoria fundamentada no pressuposto de uma sociabilidade qualificada como "natural" pelo fato de estarmos inscritos no quadro teórico de uma ordem moral (Emílio não nasce naturalmente sociável, mas torna-se sociável segundo a natureza ${ }^{20}$ ), muito embora trate-se de uma sociabilidade estabelecida necessariamente por força das "relações das coisas". Tudo ocorre como se, na passagem da piedade para a estima natural e, posteriormente, para o juízo

18 Rousseau utiliza "sentimens de sociabilité" no capítulo da religião civil no Contrato em referência ao substrato passional da ordem civil instituída no ato do pacto (Rousseau, 1964b, p. 468). Em língua francesa, o sintagma aparece nas traduções que Barbeyrac faz do Direito da guerra e da paz, de Grotius (cf. Discurso preliminar, § IX), e do Direito da natureza e dos povos, de Pufendorf (cf. livro II, cap. 3 , § 15).

19 No Discurso sobre a desigualdade, é no momento em que surge a divisão do trabalho que as patologias da ordem social se tornam incuráveis: "As coisas nesse estado poderiam ter permanecido iguais se os talentos fossem iguais [...]” (Rousseau, 1964a, p. 174). Sobre esse tema, ver o livro de Thiago Vargas, Trabalho $e$ ócio: um estudo sobre a antropologia de Rousseau (2018).

20 A passagem do livro IV do Emílio que sempre causa confusão é a seguinte: "Mas se, como não se pode duvidar, o homem é sociável por sua natureza, ou ao menos é feito para tornar-se tal, só pode sê-lo por meio de outros sentimentos inatos, relativos à sua espécie, pois, considerando-se apenas a necessidade física, ela deve certamente dispersar os homens, em vez de os aproximar" (Rousseau, 1969, p. 600). Os sentimentos chamados aqui de "inatos" não dizem respeito à sociabilidade, mas, isto sim, a impulsos como o sentimento inato de justiça que, moderando a razão e combinando-se ao amor-próprio, conduzem o indivíduo à sociabilidade. Rousseau não está adotando, no Emílio, uma constituição original do homem diferente daquela adotada no Discurso sobre a desigualdade, como pode parecer à primeira vista quando lemos que "o homem é sociável por sua natureza" (aliás, seria um erro crasso afirmar qualquer tipo de contradição entre essa passagem e o Discurso). Assim como Emílio, o homem no estado de natureza do Discurso também pode tornar-se sociável "por meio de outros sentimentos inatos [a pitié, por exemplo], relativos à sua espécie"; em ambos os casos, não há um determinismo para a sociabilidade de antemão, e sim um progresso tanto do espírito humano quanto das relações sociais; progresso que depende de circunstâncias imprevisíveis, e que pode resultar em diversas constituições, variando desde a boa ordem civil até o estado de guerra de todos contra todos. Por fim, as mudanças resultantes nos indivíduos e em seu entorno, após acasos fortuitos, acabam tornando necessária a sociabilidade, "pois, considerando-se apenas a necessidade física, ela deve certamente dispersar os homens, em vez de os aproximar", o que não significa que a sociabilidade seja impossível, nem tampouco que ela se mostre necessária a priori.

\begin{tabular}{|c|c|c|c|c|}
\hline Qovista Dialectus & Ano 8 & n. 15 & Agosto - Dezembro 2019 & p. $328-361$ \\
\hline
\end{tabular}


ordenado segundo a natureza, as relações dos homens fossem progressivamente adquirindo legitimidade e estabilidade em meio às instituições graças ao respaldo das inexoráveis relações das coisas, porém, sem se tornarem absolutamente artificiais: "é preciso empregar muita arte para impedir o homem social de ser completamente artificial" (Rousseau, 1969, p. 640).

É por isso que Rousseau aparentemente define a consciência de modo contraditório na Profissão de fé do vigário saboiano, primeiro, admitindo que ela é um hábito e "obra dos preconceitos", mas depois, afirmando categoricamente que a consciência é um “instinto divino" (Rousseau, 1969, pp. 566 e 600). Tal paradoxo da consciência no Emílio pode ser analisado no quadro da ideia de "desnaturação", entendendo-se os atos da consciência como realizações de "segunda natureza"; porém, por não haver espaço neste artigo para tal excurso, deixarei essa explicação para outra oportunidade. (Limito-me a dizer que Rousseau pensa em termos de um justo meio da consciência, cujos atos estariam situados, esquematicamente falando, entre os sentimentos inatos e os hábitos adquiridos - eis aí o sentido preciso de "ordre des choses" que comentei na nota sobre as "três educações".) O que realmente importa para o objetivo deste trabalho é comentar um dos trechos mais importantes da Profissão de fé, quando Rousseau descreve formalmente o mecanismo da consciência; trecho no qual podemos notar nada menos do que um esquema empirista de reconhecimento de diferenças inscrito no quadro de uma comunidade de indivíduos aptos a exercerem o juízo moral "segundo a natureza", ou seja, segundo as "verdadeiras relações das coisas": "[...] é do sistema moral formado por essa dupla relação, consigo mesmo e com seus semelhantes, que nasce o impulso da consciência" (Rousseau, 1969, p. 600, meus os itálicos).

A magnitude dessa definição está em sua generalidade. O "sistema moral" que propicia o "impulso da consciência" pode ser apreciado de dois pontos de vista: do eu relativo a si mesmo e do eu relativo ao mundo; ou seja, trata-se de uma representação complexa envolvendo indivíduo e coletividade; um "modelo" (eis o termo utilizado hoje) de psicologia moral que se presta tanto às teorias organicistas do Estado, como ver-se-á em Hegel, segundo as quais os indivíduos não podem ser concebidos isoladamente, isto é, fora das relações que constituem o organismo social, quanto às teorias atomistas da sociedade, como a de Hobbes e de Locke, que pressupõem o indivíduo como partícula elementar do conglomerado civil. Exemplo claro dessa ambivalência do referido "sistema" na teoria política de Rousseau é o conceito de vontade geral: não se trata da soma das vontades particulares, pois, do ponto de vista do bem comum, o interesse do corpo político é maior do que a somatória dos interesses

\begin{tabular}{|c|c|c|c|c|}
\hline Qonista Dialectus & Ano 8 & n. 15 & Agosto - Dezembro 2019 & p. $328-361$ \\
\hline
\end{tabular}


individuais; mas, em contrapartida, tampouco se trata de uma vontade que existe anteriormente ao pacto que instaura a ordem civil, uma vez que a vontade geral é obra de arte dos homens reunidos em forma de associação, sendo produzida num movimento de expansão do domínio dos interesses locais, como demonstra Bruno Bernardi (2006) ao tratar da generalização dos interesses particulares. A generalidade do "sistema moral" das consciências também se verifica no problema dos conflitos: não é preciso pressupor um estado de natureza onde os indivíduos estão sempre na iminência de uma guerra de todos contra todos (nesse sentido, o estado de natureza de Rousseau é mais geral que o de Hobbes), assim como não é preciso admitir de antemão que as relações internas do corpo político são relações de conflito (como em Maquiavel, que parte do ordenamento conflituoso entre o povo e os grandes), uma vez que até mesmo o conflito estrutural entre governo e soberano (os magistrados tendem necessariamente a usurpar a autoridade do soberano) só aparece na exposição em termos de um movimento de desordenamento, ou seja, o conflito é efeito de uma corrupção produzida por desarranjos internos na estrutura mesma da ordem ideal (a das "verdadeiras relações"), semelhante a uma patologia tumoral resultante de oncogênese que, por causas nem sempre explicáveis, surge num organismo originalmente saudável. Em Rousseau, o conflito não preexiste à gênese do conflito, assim como as facções do corpo político não preexistem à instituição do próprio corpo mediante o pacto civil.

\section{O sistema da atração moral}

Notemos na definição de consciência em Rousseau a palavra "impulso", cujo uso é de extrema relevância. O reconhecimento das consciências ali implicado é semelhante a um móbile do universo moral. Porém, não à maneira do puro mecanicismo, pois, afinal de contas, os corpos moventes são objetos morais, a saber, pessoas, o que torna a analogia imperfeita, para não se dizer, extremamente problemática. De todo modo, a despeito dos limites da metáfora, uma coisa é certa: é graças ao reconhecimento entre as pessoas - entendidas como agentes morais e conscientes acerca de si mesmas - que os laços sociais se formam. Sem o jogo de impulsos das consciências não haveria relações entre as pessoas e, por conseguinte, não haveria formação de nenhum tipo de arranjo intersubjetivo que tornasse possível a emergência da ordem civil; a mera existência de consciências capazes de refletirem acerca de si mesmas não basta para a constituição da trama social. Por outro lado, isso não significa que, para haver trama social, as relações entre as consciências devam ser materializadas, como 
quando as pessoas assinam um documento em papel para declararem que pactuam entre si. $\mathrm{Na}$ verdade, o sistema moral de Rousseau prevê uma combinação dessas duas instâncias. Antes do estabelecimento das leis positivas, é preciso que, além do reconhecimento íntimo do eu que se relaciona consigo mesmo, existam também "sentimentos de sociabilidade" manifestos na conduta cotidiana das pessoas. Uma vez admitido tal esquema, as instituições positivas podem ser vistas como bom desdobramento de uma ordem passional bem configurada. Assim, para falarmos em ordem social no modelo rousseauniano, somos forçados a admitir que, sem o ordenamento prévio do substrato passional, a sociedade jamais poderia ser erigida efetivamente de maneira estável. Seria absurdo falar de um conflito fundado em razões antes de se chegar ao momento da emergência da razão na história de Emílio. Tal conclusão, faço questão de afirmar, é válida não apenas num quadro sincrônico, mas também em perspectiva diacrônica, pois a démarche do Emílio é tanto lógica (é uma história conjetural) quanto cronológica (é uma história de vida).

Ao utilizar a expressão "impulso da consciência", percebemos o curioso fenômeno do compartilhamento do léxico da física, cujo campo semântico se abre aos registros de discurso das outras ciências. O grande paradigma científico é, obviamente, Isaac Newton $^{21}$. Muito já foi dito acerca da recepção de Newton e da transposição de suas ideias para outros quadros de pensamento da época, e isso, vale notar, não apenas no registro das ciências. Basta mencionarmos o estudo de Margaret Jacob (1976) sobre a aplicação do newtonianismo no contexto político em que é gestada a revolução inglesa por parte de filósofos divulgadores das ideias de Newton, como Boyle e Clarke. Um outro trabalho interessante, mas igualmente circunscrito ao mundo de língua inglesa, é o de Helène Metzger (1938), que relaciona os quadros teóricos da atração universal e da religião natural no século XVIII para discutir casos de aplicação das ideias de Newton do ponto de vista da moral e da religião. Peter Gay (1977, p. 126) nos fornece uma contextualização mais abrangente ao falar que o nome de Newton representava "um estilo científico de pensamento" para toda uma geração de pensadores, até mesmo para além das ilhas britânicas. A repercussão do

21 Na Questão 31 da Parte III da Óptica, Newton escreve: "O que chamo de atração pode-se dar por impulso ou por algum outro meio que desconheço. Uso esta palavra aqui apenas para expressar qualquer força pela qual os corpos tendem um para o outro, seja qual for a causa. Pois devemos aprender, pelo exame dos fenômenos da natureza, quais corpos se atraem e quais são as leis e propriedades da atração, antes de investigar a causa pela qual a atração se efetua" (Newton, 1996, pp. 274-275). Veja-se nesse trecho o essencial do 'programa' newtoniano, menos empenhado em inferir causas com base em conceitos do que em descrever os fenômenos tais como são observados na experiência material. Sobre o uso flexível da palavra "impulse" do ponto de vista da "filosofia" de Newton, cf. a compilação de A. Janiak em Philosophical Writings (2004, pp. 64, 78, $86,132)$.

\begin{tabular}{|c|c|c|c|c|}
\hline Qovista Dialectus & Ano 8 & n. 15 & Agosto - Dezembro 2019 & p. $328-361$ \\
\hline
\end{tabular}


newtonianismo na França se dá graças aos escritos de Voltaire e, de um ponto de vista mais científico, às obras de Maupertuis. Rousseau, como sabemos, era leitor de Voltaire e de Maupertuis, além de sofrer influência do newtonianismo de outros autores, como Boerhaave (na química e na fisiologia) e Buffon (na história natural). É, pois, bastante compreensível que Rousseau não apenas cite Newton, mas ainda o qualifique como um dos "preceptores do gênero humano" (Rousseau, 1964a, p. 29).

Nesse quadro onde o newtonianismo era sinônimo de esquema de inteligibilidade dos fenômenos da natureza, não nos parece absurdo admitir elementos das teorias de Newton na ciência das paixões de Rousseau: no "sistema" do Emílio, é como se, ao falar em impulso, Rousseau pensasse numa causa motora perpassando a trama formada por "verdadeiras relações" de consciências que se reconhecem entre si como semelhantes. E aqui, reconhecimento significa tanto impulso quanto atração, pois o próprio Newton admitia que esses termos eram intercambiáveis, como explica Jaucourt no verbete "Impulsion" da Enciclopédia. Ora, apesar da relevância da questão, não precisamos perder tempo com discussões acerca da natureza do impulso, pois o fato é que tal palavra dizia respeito à verdade factual do movimento dos corpos materiais, não apenas no âmbito do senso comum, mas também entre os philosophes, pois basta lembrarmos que Voltaire, nas Cartas filosóficas, defende Newton argumentando que a descrição do fenômeno não é menos importante que as hipóteses sobre as causas do fenômeno: "O primeiro anatomista que disse que o braço se mexe porque os músculos se contraem ensinou uma verdade incontestável aos homens. Deveríamos sentir-nos desobrigados diante dele por não ter sabido por que os músculos se contraem?" (Voltaire, 1973, pp. 34-35). Daí, como que por uma espécie de mimese cognitiva em relação a esse common sense, os filósofos, empolgados pelo espírito newtoniano de seu tempo, não hesitam em transpor tais esquemas de inteligibilidade para os modelos dos discursos de moral. Polêmicas à parte quando à diferença de registros dos textos de Rousseau e Newton, o intuito aqui, como lemos com clareza na Profissão de fé, é conceber um móbile necessário para o sujeito livre que possa ser representado por regras morais tão necessárias quanto às leis da física:

[...] Prendendo-se de início às relações primitivas, vê-se como os homens devem ser afetados por elas, e que paixões delas devem nascer; vê-se que é em reciprocidade ao progresso das paixões que essas relações se multiplicam e se estreitam. É menos a força dos braços que a moderação dos corações que torna os homens independentes e livres. (Rousseau, 1969, p. 524)

A fórmula do impulso: combinar a "moderação dos corações" e o "progresso das paixões" de tal maneira a produzir relações afetivas que "se multiplicam e se estreitam". 
Como fazer isso? A física newtoniana era uma das maneiras legítimas de se defender um princípio que, podendo ser inferido com base em seus efeitos empiricamente verificáveis, necessita apenas de um recurso à autoridade de Newton para ser legitimado. ( $\mathrm{Na}$ verdade, havia diversas referências de grande autoridade, como o Ensaio de Locke, o tratado de fisiologia de Boerhaave, o Espírito das leis de Montesquieu, a história natural de Buffon etc.). Polêmicas à parte quanto à legitimidade de tal aplicação do newtonianismo no plano da moral, o fato é que, uma vez adotado o modelo dos físicos, os filósofos do século XVIII se dispensavam de ter que explicar minuciosamente a gênese da sociabilidade. Ao falar de uma lei moral sob a bandeira do empirismo moderno, Rousseau traz para a terra o fato material das órbitas celestes: eis o sentido daquela lei "que não se grava nem no mármore nem no bronze, mas nos corações dos cidadãos; que faz a verdadeira constituição do Estado" (Rousseau, 1964b, p. 394). Veja-se que os impulsos de reconhecimento recíproco operam no domínio da necessidade dos "sentimentos naturais", e é por isso que eles podem ser considerados legítimos e cientificamente representáveis do ponto de vista do método experimental:

Se, portanto, o reconhecimento é um sentimento natural e se não destruirdes seu efeito por vossa culpa, podeis ter certeza de que vosso aluno, começando a perceber o valor de vossas atenções, será sensível a elas, contanto que não lhe tenhais atribuído um preço, e de que elas vos darão em seu coração uma autoridade que nada poderá destruir. (Rousseau, 1969, p. 522)

O texto acima confere destaque às "atenções" do educador que cativam cada vez mais o interesse aluno. Novamente, infere-se daí relações por impulso ou atração. Entre o educador e o aluno, de fato há ação e reação, como num jogo de forças físicas envolvendo causas e efeitos, com tudo ocorrendo de modo observável do ponto de vista da experiência nos esquemas de inteligibilidade da doutrina empirista. Daí o sentido de se imaginar o impulso da consciência como manifestação da lei do amor entre corações, entendendo-se a palavra tanto no sentido romântico (se pensarmos nos leitores alemães do Emílio no século XIX) quanto no registro do mecanicismo: algo como um fenômeno descrito como consciências semelhantes que se sentem naturalmente atraídas uma pela outra na proporção de suas carências. Trata-se, por assim dizer, de uma inclinação de buscar no outro a satisfação do desejo por reconhecimento, o que, em Rousseau, nos remete à hipótese do Ensaio sobre a origem das línguas: "No momento em que um homem foi reconhecido por um outro como um ser sensível, pensante e semelhante a ele, o desejo ou a necessidade de comunicar-lhe os próprios sentimentos e os próprios pensamentos fez com que procurasse os meios de fazê-lo" (Rousseau, 1995, p. 375). Nessa mesma perspectiva, o genebrino também fala do reconhecimento na Carta a d'Alembert sobre os espetáculos, desta vez, mobilizando o 
esquema médico de Ares, águas e lugares para especificar a demanda por amor nas regiões de clima quente, onde os agentes livres preocupam-se mais com seus afetos do que com a sobrevivência, dizendo portanto aimez-moi em vez de aidez-moi (Rousseau, 1995, p. 408). Numa perspectiva inversa e complementar a esta, a questão do reconhecimento afirmado pela via de sua negação - "desprezo", como o próprio Honneth concebe em sua teoria, ou “desconhecimento" [méconnaissance] na visão de Paul Ricoeur (2004) ${ }^{22}$ - não seria uma fórmula estranha para Rousseau, que também pensa em obstáculos ao desejo por reconhecimento como nas tópicas da recusa do amor e dos mal-entendidos (cf. Starobinski, 1971). Ora, é óbvio que, na Carta a d'Alembert e no Ensaio, estamos muito longe de uma demanda política à maneira do modelo de reconhecimento da teoria de Axel Honneth; porém, é importante observar que existe de fato um modelo de reivindicação (i.e., uma atividade do espírito que busca suprir uma carência) de reconhecimento entre sujeitos morais situados numa determinada constituição civil e, em certa medida, acometidos por patologias sociais.

O modelo das reivindicações que emergem das ordens patológicas pode ser pensado nos termos de uma relação entre demandas puramente jurídicas e demandas interessadas. A pergunta nesse caso é: quais as condições para falarmos em reivindicação por reconhecimento, não na lógica de um estado de guerra como o do Leviatã de Hobbes, mas na perspectiva de um consenso equitativo capaz de combinar interesses e regras formais? A resposta no contexto da obra política de Rousseau é: ordenando a razão segundo as paixões, e não o inverso. Ora, o quadro teórico para se refletir acerca desse problema é o da relação entre teoria e prática que Salinas Fortes analisa em sua tese Rousseau: da teoria à prática. De acordo com o comentador brasileiro, vale notar que, no Contrato social, a ordem jurídica estabelecida pelo pacto civil deve ser complementada por uma ordem passional que somente o legislador pode instaurar, pois, do ponto de vista da prática, sem o legislador não há consenso, de tal modo que, no Contrato, a teoria só pode ser efetivada mediante o jogo das paixões que os próprios jogadores desconhecem ou desprezam: “O corpo político não é assim apenas um sistema de relações jurídicas entre os indivíduos: este sistema é apenas a sua ossatura.

22 Ricoeur (2004) contrapõe reconnaissance e méconnaissance a fim de examinar a dificuldade originária do estatuto positivo para a ideia de reconhecimento. Ele recorda o exemplo do criminoso, que "se faz reconhecer na singularidade rebelde diante da lei que ele desconhece” (ibid., p. 371). Na interpretação que Ricoeur faz da teoria de Honneth, o desprezo [mépris], entendido como expressão do desconhecimento nas relações sociais, é a condição do reconhecimento. Buscando o fundamento da ideia de reconhecimento, Ricoeur considera, por um lado, que a oposição entre reconhecimento e desconhecimento desvela a "dissimetria originária entre o eu e o outro, dissimetria que não abole a reciprocidade enquanto mutualidade" (ibid., p. 373), e por outro, que a produção do reconhecimento é, via de regra, sinônimo de "conflitualidade interminável" (ibid., p. 372), justificando assim que falar de reconhecimento significa necessariamente falar de "luta por reconhecimento".

\begin{tabular}{|c|c|c|c|}
\hline Qenista Dialectus & \begin{tabular}{|l|l|} 
Ano 8 & n. 15 \\
\end{tabular} & Agosto - Dezembro 2019 & p. $328-361$ \\
\hline
\end{tabular}


Contudo, mais do que isto, trata-se de uma realidade essencialmente de ordem afetiva" (Salinas Fortes, 1976, p. 89). Nunca é demais lembrar: o princípio regulador da "sociedade bem ordenada" 23 do Contrato não é uma razão de Estado, mas a vontade geral, ou seja, um princípio que diz respeito aos dispositivos passionais que movimentam o corpo político. De modo análogo, no Emílio, não bastam as regras de civilidade, pois elas não passam de "ossatura" das "verdadeiras relações" da ordem moral; antes, é preciso que elas sejam amparadas por uma ordem passional mais conveniente com a natureza prioritariamente apaixonada do ser humano. Emílio já é um ser "pensante", de tal modo que resta ao educador tornar seu aluno "amoroso e sensível" (Rousseau, 1969, p. 481). Sem amor e sensibilidade, Emílio não passaria de uma máquina ou de um esqueleto sem carne.

Com efeito, é através da língua das relações amorosas - língua esta articulada na rede de comunicação dos impulsos - que as consciências comunicam suas demandas por reconhecimento recíproco, como se a lei da consciência fosse, no fundo, uma versão moral da lei da atração universal de Newton: "Quando amamos, queremos ser amados" (Rousseau, 1969 p. 668). Tal fórmula é construída para expressar a conexão necessária entre causa (o próprio amor) e efeito (o desejo de ser objeto do amor alheio). Todavia, o quadro patológico implica, como todos sabem, em excessos, e daí a necessidade de elementos de moderação do amor. E eis que se chega ao momento de uma nova "cena": a das relações entre amigos. Veremos no próximo artigo que os impulsos das consciências podem ser moderados pelas relações de reconhecimento derivadas de um poderoso remédio, a saber, o sentimento de amizade:

[...] nada tem tanto peso para o coração humano quanto a voz da amizade reconhecida, pois sabemos que ela só nos fala por nosso bem. Podemos acreditar que um amigo se engana, mas não que nos queira enganar. Às vezes resistimos a seus conselhos, mas nunca os desprezamos. (Rousseau, 1969, p. 522).

Tudo se passa como se o sentimento de amizade fosse um remédio para as ações desmedidas do agente movido puramente por paixões ligadas ao amor. A esse respeito, Rousseau faz outra conexão necessária: "da necessidade de uma amante logo nasce a de um amigo" (Rousseau, 1969, p. 494). Isso porque a relação entre amigos é acometida de menos excessos do que a relação entre amantes, o que torna evidente que uma sociedade não poderia ser constituída exclusivamente por indivíduos que seguissem o mandamento de Cristo, que confunde amor de si e amor-próprio: "Amarás ao teu próximo como a ti mesmo" (Evangelho

23 A expressão "société bien ordonné" aparece no capítulo "Da sociedede geral do gênero humano" no Manuscrito de Genebra (cf. Rousseau, 1964a, p. 289).

\begin{tabular}{|c|c|c|c|}
\hline Qevista Dialectus & \begin{tabular}{|l|l|} 
Ano 8 & n. 15
\end{tabular} & Agosto - Dezembro 2019 & p. $328-361$ \\
\hline
\end{tabular}


de Mateus, 22: 39). Como notará Rousseau, o cristianismo não colabora para a estabilidade das relações civis por pautar as relações de amor entre os homens na inatingível relação desinteressada entre Cristo e os homens: "amai-vos uns aos outros assim como eu vos amei" (Evangelho de João, 15: 12). Ora, que amor é esse senão o amor de si do indivíduo présocial? Um sentimento natural, certamente, porém, inviável para o funcionamento da ordem civil. Afinal, os amigos podem até gostar um do outro, mas não a ponto de dispor a própria vida como se a paixão do amor-próprio pudesse ser obnubilada sem hipocrisia. Como Rousseau bem alerta no capítulo da religião civil do Contrato, uma sociedade de cristãos seria impossível, pois "uma sociedade de verdadeiros cristãos não seria uma sociedade de homens" (Rousseau, 1964b, p. 465). Isso porque o amor de Cristo é desinteressado, ao passo que o amor-próprio segue necessariamente a par e passo junto com o motor do interesse. Afinal, como interpreta Bruno Bernardi, se admitirmos que Rousseau expõe suas ideias à maneira de um sistema filosófico, podemos entender que "a filosofia de Rousseau é inteiramente uma filosofia do interesse" (Bernardi, 2006, p. 283). No fundo, uma filosofia do amor-próprio, poderíamos dizer.

No tocante à consciência moral no Emílio, não me aprofundarei mais do que isso neste artigo, pois já tratei longamente do assunto em outros lugares. ${ }^{24}$ Isso posto, para não alargar ainda mais esta exposição, limito-me a explorar o seguinte paralelo conceitual: assim como o sentimento de estima pode ser visto como o embrião do juízo moral, de forma análoga, podemos considerar o reconhecimento entre semelhantes como um protótipo daquilo que Rousseau denomina "sentimentos de sociabilidade".

\section{Economia dos afetos: o reconhecimento como condição da sociabilidade}

Vimos nas seções anteriores que o desenvolvimento da estima traz sempre em seu bojo o risco de corrupção, sendo esse risco tão mais grave quanto mais rapidamente a estima se desenvolve. Um desenvolvimento rápido demais pode permitir que o sentimento de préjuízo natural se transforme num juízo mais de acordo com a opinião pública do que com as "verdadeiras relações": nesse caso, estaríamos falando de um prejuízo propriamente dito (intolerável portanto). $\mathrm{Na}$ visão pedagógica de Rousseau, os atos de reconhecimento resultantes de uma estima pública precoce expressam, não a voz da natureza, e sim os

24 Sobre a relação entre religião e política em Rousseau, ver meu livro (Kawauche, 2013). Sobre a consciência, ver o artigo "Consciência e sentimento no Emílio de Rousseau", que espero conseguir publicar em breve.

\begin{tabular}{|c|c|c|c|c|}
\hline Q Ronista Dialectus & Ano 8 & n. 15 & Agosto - Dezembro 2019 & p. $328-361$ \\
\hline
\end{tabular}


preconceitos da sociedade. Mais especificamente, é como se, no modelo do "sistema moral" das consciências, houvesse uma quebra de isonomia na estrutura da "dupla relação" e Emílio passasse a priorizar mais a relação "consigo mesmo" em detrimento da relação "com seus semelhantes", distorcendo assim, na economia dos afetos, as "relações dos homens". A sagacidade da crítica de nosso autor está em denunciar que a fonte das misérias da ordem civil não é natural, e sim produto de um desequilíbrio acidental das relações morais por conta da multiplicação desordenada das paixões. Numa palavra: a inclinação ao egoísmo é um mal, porém, não pelo egoísmo em si, mas pelo fato de configurar-se como um ordenamento do amor-próprio que não propicia a contrapartida da produção dos sentimentos de sociabilidade. A seguinte citação é um belo exemplo do tipo de processos imperceptíveis que Rousseau analisa em sua física do reconhecimento:

Queremos obter a preferência que concedemos; o amor deve ser recíproco. Para ser amado é preciso tornar-se amável; para ser preferido é preciso tornar-se mais amável do que outro, mais amável do que qualquer outro, ao menos aos olhos do objeto amado. Daí os primeiros olhares para os semelhantes; daí as primeiras comparações com eles, daí a emulação, as rivalidades, o ciúme. Um coração cheio de um sentimento que transborda gosta de se alargar: da necessidade de uma amante logo nasce a de um amigo. Quem sente quanto é doce ser amado gostaria de sê-lo por todo mundo, e nem todos poderiam querer preferências sem que houvesse muitos descontentes. Com o amor e a amizade nascem as dissensões, a inimizade, o ódio. Do seio de tantas paixões diversas, vejo a opinião erguer para si mesma um trono inabalável, e os estúpidos mortais, submissos ao seu império, fundamentarem sua própria existência apenas nos juízos de outrem. (Rousseau, 1969 p. 494)

O texto acima nos lembra tanto dos estudos de dinâmica em Newton quanto da história das doenças de Hipócrates. Nele Rousseau descreve a demanda por reconhecimento impulsionada pelo amor-próprio, tendo inclusive o cuidado de receitar um remédio moderador que é o sentimento de amizade. O diagnóstico começa mostrando que a preferência por si mesmo, paixão absoluta que remonta ao amor de si, torna-se paixão social quando é introduzida no quadro das relações humanas: "para ser preferido é preciso tornar-se mais amável do que outro". Após esse passo inicial, o movimento de desnaturação da ordem descrita vai dos "primeiros olhares para os semelhantes" e termina nas relações pautadas pela opinião pública, numa sequência onde as comparações engendram emulação, rivalidade, crimes, dissensões, inimizade, ódio etc. Veja-se que, diante da multiplicação excessiva dos sentimentos de amor, nem o pharmakon dos sentimentos de amizade é eficaz o bastante para conter a produção desmedida dos sentimentos nocivos às relações humanas, pois trata-se de uma verdade empírica que "nem todos poderiam querer preferências sem que houvesse muitos descontentes”. Em linhas gerais, o movimento descrito é análogo àquele do Discurso sobre a origem da desigualdade no instante em que a vaidade emerge sub-repticiamente no 
episódio do canto e da dança: "Cada qual começou a olhar os outros e a querer ser olhado por sua vez, e a estima pública teve um preço" (cf. Rousseau, 1964a, p. 169). Dessa perspectiva, ressalta-se tanto no Discurso quanto no Emílio uma ruptura trágica com relação ao modo de vida condicionado pelo amor de si; os homens passam a reivindicar reconhecimento lutando por "estima pública", e progressivamente, são movidos em função do "preço" que, de modo cada vez mais intenso, anima os sentimentos de sociabilidade e engendra novas patologias sociais malignas.

Tal quadro clínico nos mostra que, embora os laços civis sejam efetivados pela dinâmica dos jogos do amor-próprio, não há garantia quanto à harmonia do resultado final na sociedade estabelecida, pois o desdobramento das relações entre as consciências dos agentes que demandam reconhecimento dos demais pode ser, de acordo com as circunstâncias, tanto a boa sociabilidade quanto o estado de guerra de todos contra todos. E nem poderia ser diferente, pois, afinal, trata-se de uma luta por reconhecimento ${ }^{25}$ cuja realidade é determinada pela configuração imprevisível que a própria luta assume de acordo com seus movimentos de sua constituição. Nos termos da educação de Emílio, sentir as verdadeiras relações do homem significa estar implantado numa rede de sentimentos que produz o tecido da sociabilidade, se não de modo geral, pelo menos à maneira como Rousseau concebe os laços sociais, isto é, considerando os progressos da sociabilidade como imponderáveis quanto ao seu bom resultado. Em termos dicotômicos, o problema pode ser parametrizado por seus resultados contrastantes. Se, na fase madura da ordem civil, o liame da constituição civil adquire uma forma estável e os impulsos da consciência se manifestam como verdadeiros "sentimentos de sociabilidade", tal manifestação deve ser considerada um entrelaçamento exitoso entre o indivíduo e a sociedade, ou, do ponto de vista da ordem das paixões, uma boa metamorfose do amor de si em amor-próprio. Em contrapartida, se o progresso das instituições acompanha preferencialmente a face nociva dos desdobramentos do amor-próprio, a arte de tecer relações sociais tende ao fracasso, uma vez que a consciência moral, cuja voz é baixa, torna-se completamente inaudível para alertar Emílio acerca dos perigos trazidos pela multiplicação desordenada das paixões. $\mathrm{Na}$ analogia médica, os vícios adquiridos correspondem a sintomas particulares de causas mais gerais que neste artigo denominamos "patologias do social".

25 Emprego aqui essa expressão, porém, alertando que não se trata de "luta" no sentido da teoria de Honneth, pois a questão no Emílio é estritamente moral, sendo apenas indiretamente ligada aos movimentos da política. Para a interpretação política da "luta por reconhecimento" em Rousseau, remeto o leitor aos textos de Pénigaud de Mourgues indicados na bibliografia.

\begin{tabular}{|c|c|c|c|c|}
\hline Qonista Dialectus & Ano 8 & n. 15 & Agosto - Dezembro 2019 & p. $328-361$ \\
\hline
\end{tabular}


Colocada dessa maneira, a questão "como ordenar as paixões humanas?" seria inescapável de uma "metafísica dos costumes", no sentido kantiano de exposição dos princípios a priori que tornam necessário o fazer ou o não fazer, haja vista a necessidade do educador para orientar suas intervenções. Ora, as questões que ligam a teoria moral e a teoria social em Rousseau são muito abstratas e, de todo modo, não dizem respeito ao objeto deste artigo. Se então deixarmos de lado as complicações epistemológicas da educação moral do Emílio, o que nos importa notar nas primeiras páginas do livro IV é tão somente a teoria social empírica que ali aparece. A análise deste trabalho se limita ao deslocamento realizado por Rousseau nos movimentos da ordem física rumo à constituição da ordem moral do ponto de vista das faculdades que tornam o aluno um indivíduo apto a pertencer à constituição civil. Da "metafísica" das paixões aqui abordada, interessa-nos tão-somente a inserção social do aluno orientada pelo princípio do meio-termo entre natureza e cultura: "Emílio não é um selvagem destinado aos desertos; é um selvagem feito para morar nas cidades" (Rousseau, 1969, pp. 483-484). Na reconstrução do pensamento aqui investigado, tal princípio encontra sua figura prática na cena pedagógica do ateliê de marcenaria; o momento de dar ao aluno um ofício serve como porta de entrada para a vida pública. Grosso modo, é como se, na perspectiva dos conhecimentos empíricos de Emílio, as cadeias de causalidade observadas no livro III durante o aprendizado da "arte puramente mecânica" da carpintaria fossem transportadas para um novo modelo de representação das relações necessárias de uma outra fábrica $^{26}$ : a da economia da sociedade civil. Entretanto, Rousseau não pretende com a formulação desse modelo justificar uma ontologia do social, pois, como já vimos, seus interesses ligados à economia do corpo político são bem mais práticos e passam longe de uma investigação acerca da essência da sociedade. É da literatura que o educador de Emílio propõe a ilustração para a fábrica de relações dos homens: estamos falando da história do náufrago na ilha selvagem escrita por Daniel Defoe. No célebre romance, os fatos que precedem a chegada à ilha importam menos do que as cenas assistidas na própria ilha; isso porque ali as verdadeiras relações das coisas não são princípios a priori das técnicas que Robinson inventa para sobreviver, mas, isto sim, fatos materiais empiricamente observáveis. Defoe expõe em

26 No sentido da "fabrica" de Andreas Vesalius em De humani corporis fabrica (1543), ou seja, uma composição do corpo (no caso, um corpo político) cujo conhecimento depende da arte da anatomia. Num certo sentido, o ateliê de marcenaria do Emílio pode ser compreendido à luz do mesmo modelo de inteligibilidade da medicina moderna, pois trata-se de descrever a ordem da economia nas relações humanas por meio de uma arte (como a medicina) ou uma ciência (como a ciência da legislação). A palavra fabrica expressa ambos os sentidos.

\begin{tabular}{|l|l|l|l|l|}
\hline Revista Dialectus & Ano 8 & n. 15 & Agosto - Dezembro 2019 & p. $328-361$ \\
\hline
\end{tabular}


linguagem romanesca a ideia da ordem moral na perspectiva dos conhecimentos úteis na formação do aluno de Rousseau:

Robinson Crusoé em sua ilha, [...] eis um objeto interessante para qualquer idade [...]. O meio mais seguro de elevar-se acima dos preconceitos e ordenar seus juízos sobre as verdadeiras relações das coisas está em colocar-se no lugar de um homem isolado e julgar tudo como esse homem deve ele mesmo julgar o que diz respeito à sua própria utilidade. (Rousseau, 1969, p. 455)

A fim de que Emílio conheça a sociedade, Rousseau transforma a narrativa de Robinson numa experiência do pensamento. Na terminologia do século XVIII, dizemos que Robinson é uma "hipótese", pois esse era o termo científico utilizado para descrever, por exemplo, o estado de natureza nas teorias contratualistas. Na ciência do homem exposta por Rousseau no Emílio, o objeto é a trama social, e a hipótese é que a trama social deve ser analisada por etapas: começando pelo indivíduo, depois passando pelas diversas relações - de coisas e de homens - que vão se estabelecendo, até que finalmente, chega-se junto com Robinson a uma compreensão abrangente da coletividade. Ou seja, a regra de ordem no método de análise em Emílio é partir da unidade até chegar à diversidade ${ }^{27}$; daí se entende que a face observável dessa trama se revele progressivamente aos olhos de Emílio, indo do absoluto ao relativo. Primeiro, o educador expõe as "verdadeiras relações das coisas", bem conhecidas nessa etapa graças à educação dos sentidos do livro II e à lição de economia política do livro III, e somente aos poucos vai chegando, por deduções semelhantes àquelas do Discurso sobre a desigualdade, às "verdadeiras relações do homem"; estas, por serem diversas e confusas, podem desencaminhar o juízo moral de Emílio ainda em formação, e por isso o pedagogo deve ser cauteloso para evitar complicações excessivas nas lições que dá ao aluno. Evidentemente, há sempre o risco de que a passagem dos sentimentos absolutos para os sentimentos relativos se incline para o puro egoísmo, então, o antídoto na farmacologia da ordem passional de Rousseau é o transbordamento de amor ${ }^{28}$. As relações conflituosas que perpassam a formação do sistema moral de consciências que demandam reconhecimento recíproco ficam, de certa forma, neutralizadas em seus efeitos nefastos quando o egoísmo do jovem é um egoísmo movido por amor (veremos que a amizade entra aí como um moderador

27 O primado da unidade sobre a diversidade não significa, pelas razões apresentadas na seção "Sentir o outro à maneira de Newton: da piedade à consciência", que a teoria social de Rousseau seja apenas atomista. Tratase de um método de exposição prático, e não de um primado ontológico do indivíduo em relação à coletividade.

28 Lembremos que, no Contrato social, o remédio para o surgimento das facções é a multiplicação da divisão interna: "Em havendo sociedades parciais, impõe-se multiplicar-lhes o número a fim de impedir a desigualdade entre elas, como fizeram Sólon, Numa e Sérvio" (Rousseau, 1964b, p. 372).

\begin{tabular}{|l|l|l|l|l|}
\hline Govista Dialectus & Ano 8 & n. 15 & Agosto - Dezembro 2019 & p. $328-361$ \\
\hline
\end{tabular}


de segunda ordem), donde se justifica a importância de formar Emílio como "um ser amoroso e sensível":

Depois de ter começado por exercitar o seu corpo e seus sentidos, exercitamos seu espírito e seu juízo. Finalmente unimos o uso de seus membros ao de suas faculdades; fizemos um ser ativo e pensante; só nos resta, para finalizar o homem, fazer dele um ser amoroso e sensível, isto é, aperfeiçoar-lhe a razão pelo sentimento. (Rousseau, 1969, p. 481)

A boa passagem do amor de si para o amor-próprio nessa perspectiva tem como alvo a satisfação do desejo por reconhecimento nas relações de amor e sensibilidade. Pelo caráter didático da exposição de Rousseau, nada nos desautoriza a comparar esse quadro do Emílio a uma história natural do amor-próprio, porém, apresentado numa roupagem moderna, a saber, descrito como uma experiência de laboratório. Com efeito, nesse ensaio controlado bem ao estilo das ciências empíricas da época, o $e u$ de Emílio é submetido a uma série de testes que servem para aferir aos olhos do educador - e também aos olhos do leitor - em que medida o amor se desenvolve a partir do sentimento de estima, pressupondo-se para tanto que o adolescente coleciona as ideias que vai adquirindo ao estimar-se sucessivamente na comparação de si mesmo com diversos homens. Tais comparações seriadas de ideias fazem as vezes de tábuas de categorias para a consciência, bem como para o juízo; são essas tábuas que o educador de Emílio utiliza para "aperfeiçoar-lhe a razão pelo sentimento". A vantagem de se recorrer a esse quadro econômico das paixões é que a estima se mostra enquanto objeto mensurável, de tal maneira que, na perspectiva de um progresso do entendimento, a escala de fundo que mede a estima pode extrapolar, como numa indução matemática, o campo observável do indivíduo. O resultado desse viés de análise é uma maior abrangência do próprio modelo: trata-se de investigar não apenas a metamorfose da estima em juízo moral nessa investigação do eu "amoroso e sensível" que toma a si mesmo como objeto de conhecimento, mas também, no âmbito das relações intersubjetivas, a trama instaurada pelo trabalho conjunto do próprio eu e dos eus alheios. Em outras palavras, Rousseau muda a perspectiva de "barômetro da alma" (metáfora encontrada no primeiro dos Devaneios do caminhante solitário), transformando-o num barômetro das almas, no plural, cuja aplicação diagnosticaria os diversos estados da sociedade, sem com isso deixar de medir sua própria condição interior. Do ponto de vista das causas eficientes que agem no entendimento de Emílio, podemos dizer que a passagem da medida da estima do indivíduo para a coletividade é um momento da história do espírito do aluno imaginário localizado entre, de um lado, a pura sensação física do indivíduo isolado, e de outro, o juízo moral entendido como ato da consciência amparada pela razão em meio a uma trama de relações de reconhecimento social. 


\section{Considerações para a Segunda Parte}

Antes de avançarmos para o problema da amizade como remédio, resta esclarecer que, muito embora Emílio seja piedoso (no sentido de ser movido pela simpatia em relação à miséria alheia), isso não significa que ele será um indivíduo altruísta e caridoso a ponto de esquecer-se de si mesmo. Sua formação vislumbra um homem, e não um santo. O pressuposto disso está no Discurso sobre a desigualdade: a piedade ali não deixa de funcionar como uma fonte de egoísmo do ponto de vista da natureza das coisas; no momento dos primeiros movimentos da alma, quando o homem observa o sofrimento de seu semelhante, é verdade que ele pode ser condescendente, não apenas imaginando-se no lugar do outro que sofre, mas ainda lamentando-se por compartilhar do sofrimento alheio; contudo, nessa mesma situação, o homem também pode ter uma atitude meramente egoísta na medida em que manifesta o desejo de não sofrer como o semelhante dizendo a si mesmo: ainda bem que não sofro como ele! Esse sentimento de bem-estar egocêntrico que no Discurso era apenas pressuposto, no Emílio aparece explicitamente formulado: "Se o primeiro espetáculo que o impressiona é um objeto de tristeza, o primeiro retorno sobre si mesmo é um sentimento de prazer. Vendo de quantos males está livre, sente-se mais feliz do que pensava ser” (Rousseau, 1969, p. 514). Honneth poderia muito bem ver aí uma relação de reconhecimento estabelecida por atos de desprezo.

Tanto no Discurso quanto no Emílio, há sempre o perigo de que os avanços levam à produção de vícios, o que se verifica todas as vezes que as comparações primitivas da criança são afetadas por circunstâncias que estimulam mais o bem particular do que o bem comum: por exemplo, Emílio precisa visitar pessoas doentes para experimentar sentimentos de compaixão, mas se fizer isso em excesso, acabará se tornando insensível às misérias da vida humana (seja passivamente por força do hábito, seja ativamente por desejo de não se entristecer) e, por conseguinte, ficará inclinado ao ensimesmamento ${ }^{29}$. Ou seja, ficará doente de alma por conta de um funesto desequilíbrio do "sistema moral" da consciência. Deduz-se dessa colocação do problema que as misérias podem ser reduzidas ao mínimo se o caminho trilhado por Emílio for o da via média. As intervenções do educador devem, portanto, ocorrer

$29 \mathrm{Na}$ Parte II deste artigo, pretendo analisar a seguinte passagem: “[...] as paixões imoderadas fazem sempre mais mal do que aquele que se quer evitar. Não se trata de fazer de vosso aluno um enfermeiro, um irmão de caridade, de afligir continuamente seu olhar com objetos de dor e de sofrimento [...] é preciso tocá-lo e não endurecê-lo fazendo-o assistir às misérias humanas. [...] É assim que, de tanto verem morrer e sofrer, os padres e os médicos se tornam impiedosos. Que vosso aluno conheça, portanto, a sorte do homem e as misérias de seus semelhantes; mas que não seja testemunha delas por tempo demais" (Rousseau, 1969, p. 517).

\begin{tabular}{|c|c|c|c|}
\hline Qovista Dialectus & \begin{tabular}{|l|l|} 
Ano 8 & n. 15 \\
\end{tabular} & Agosto - Dezembro 2019 & p. $328-361$ \\
\hline
\end{tabular}


na história das paixões do aluno com o propósito de moderar as experiências extremas, ajustando-se o ordenamento das paixões pelo critério do justo meio. Esquematicamente falando, podemos estabelecer um paralelismo entre, de um lado, a piedade e o reconhecimento segundo as "verdadeiras relações das coisas" na perspectiva das paixões primitivas, e de outro lado, a estima e o juízo do aluno conforme às "verdadeiras relações do homem" do ponto de vista das paixões instituídas. Longe de fazer tabula rasa das paixões originais e propor uma educação puramente positiva, Rousseau procura um equilíbrio entre natureza e cultura, apostando em intervenções para curar as desordens acidentais na sempre cambiante constituição de Emílio, o que nos permite compreender não apenas o sentido realista da pedagogia rousseauniana, mas também o fato de suas ideias jamais deixarem de estar em conformidade à ordem natural. Nesse sentido, a consciência no Emílio pode ser apreciada como resultado de um processo de formação do juízo dos homens "tais como são" (essa expressão vem do Contrato e opõe-se às leis, ou às teorias, "como podem ser"), tendo-se como aspecto errático dessa gênese certas relações de reconhecimento entre as consciências pautadas, ora pela piedade natural, ora pela opinião pública.

É a consciência bem ordenada nas trilhas da estima natural que torna possível o juízo moral segundo a natureza, fazendo com que, ao longo do percurso, Emílio se transforme num ser a uma só vez sociável e humano. Fora desse caminho salutar, nosso aluno imaginário, movido pelo amor-próprio, buscaria a armadilha da felicidade absoluta, sem se dar conta que, na verdade, a constituição do mundo humano não permite nada além de uma "frágil felicidade", a qual surge do reconhecimento da "fraqueza do homem". Rousseau diagnostica na origem da sociabilidade uma "enfermidade", referindo-se não apenas ao indivíduo em si, mas também ao lugar deste na ordem civil, haja vista a extensão do domínio da doença para a

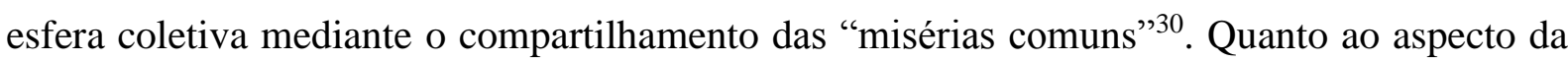
reciprocidade como condicionante da grandeza ou da miséria implicadas nas relações de reconhecimento, vale notar que Honneth, num texto anterior aos seus estudos mais aprofundados sobre Rousseau, é bem coerente com a definição rousseauniana de uma sociabilidade entre seres miseráveis. No Emílio, a sociabilidade é gerada partir de

30 A passagem em questão encontra-se no livro IV do Emílio e traz a notável ideia de que a constituição ligada à felicidade a ser estabelecida pelo educador de Emílio é frágil, pois precisa ser refeita a cada instante na história do aluno: "É a fraqueza do homem que o torna sociável; são nossas misérias comuns que levam nossos corações à humanidade: nada lhe deveríamos se não fôssemos homens. Todo apego é sinal de insuficiência: se nenhum de nós precisasse dos outros, ninguém pensaria em unir-se a alguém. Assim, de nossa própria enfermidade nasce nossa frágil felicidade" (Rousseau, 1969, p. 503). Tzvetan Todorov utilizou a expressão frêle bonheur no título de um de seus livros, e acredito que ela caberia bem como epígrafe deste artigo. 
consciências que, embora movidas por amor-próprio, reconhecem-se umas às outras como fracas e necessariamente dependentes entre si. Aquilo que Rousseau chama de "misérias comuns" para falar dos laços sociais, Honneth denomina "moral point of view": "as criaturas humanas são vulneráveis, daquela maneira específica que qualificamos de 'moral', porque devem sua própria identidade à estrutura dessa relação prática que, desde o primeiro instante, depende da ajuda mútua e da aprovação por parte de outras pessoas" (Honneth, 1997, p. 1276).

\section{REFER̂̂ENCIAS :}

BALAN, B. Premières recherches sur l'origine et la formation du concept d'économie animale. Revue d'Histoire des Sciences, v. 28, n. 4, 1975.

BERNARDI, B. La Fabrique des concepts : recherches sur l'invention conceptuelle chez Rousseau. Paris: Honoré Champion, 2006.

BROUZET, P. Essai sur l'éducation médicinale des enfants et sur leurs maladies. Paris, 1754.

BURGELIN, P. Jean-Jacques Rousseau et la religion de Genève. Paris: Labor et Fides, 1962.

CANGUILHEM, G. O conhecimento da vida. Rio de Janeiro: Forense, 2012.

CRÉTOIS, P. De Rousseau comme précurseur de la philosophie sociale : dépasser la lecture honnéthienne de Rousseau. Rousseau Studies, n. 5, 2017.

CUNNINGHAM, A. Sympathy in Man and Nature. Tese (Doutorado em Filosofia). Toronto, 1999. Department of Philosophy - University of Toronto.

DALBOSCO, C. A. Condição humana e formação virtuosa da vontade: profundezas do reconhecimento em Honneth e Rousseau. Educação e Pesquisa, v. 40, n. 3, 2014.

DELON, M. L'Idée d'énergie au tournant des Lumières (1770-1820). Paris: PUF, 1988.

DENT, N. Rousseau: An Introduction to his Psychological, Social and Political Theory. Oxford: Basil Blackwell, 1988.

DIDEROT, D.; D’ALEMBERT, J. Enciclopédia, ou Dicionário razoado das ciências, das artes e dos ofícios, v. I. São Paulo: Edunesp, 2015.

Encyclopédie, ou Dictionnaire raisonné des sciences, des arts et des métiers. 1751-1772. Disponível em <http://encyclopedie.uchicago.edu>. Acessado em 15/11/2019.

DUCHESNEAU, F. L'Empirisme de Locke. Le Haye: M. Nijhoff, 1973.

GAY, P. The Enlightenment: An Interpretation, v. II. New York: Norton, 1977.

HIPÓCRATES. Epidemies I; Airs, Waters, Places. In: JONES, W. H. S. (Ed.). Hippocrates, v. I. Cambridge: Harvard University Press, 1967.

HONNETH, A. Reconnaissance. In: CANTO-SPERBER, M. (Org.). Dictionnaire d'éthique et de philosophie morale. $2^{\mathrm{a}}$ ed. Paris: Presses Universitaires de France, 1997.

\begin{tabular}{|c|c|c|c|}
\hline Qovista Dialectus & \begin{tabular}{|l|l|} 
Ano 8 & n. 15 \\
\end{tabular} & Agosto - Dezembro 2019 & p. $328-361$ \\
\hline
\end{tabular}


La sociedad del desprecio. Madrid: Trotta, 2011.

Abismos do reconhecimento: o legado sociofilosófico de Jean-Jacques Rousseau. Civitas, v. 13, n. 3, 2013. [Texto original: Untiefen der Anerkennung. Das sozialphilosophische Erbe Jean-Jacques Rousseaus. WestEnd - Neue Zeitschrift für Sozialforschung, v. 9, n. 1/2, 2012.]

Freedom's Right: The Social Foundations of Democratic Life. Columbia University Press, 2014.

HUME, D. Tratado da natureza humana. $2^{\mathrm{a}}$ ed. São Paulo: Edunesp, 2009.

JACOB, M. The Newtonians and the English Revolution, 1689-1720. Ithaca: Cornell University Press, 1976.

JAEGER, W. Paideia: a formação do homem grego. $4^{\text {a }}$ ed. São Paulo: Martins Fontes, 2001.

JAMES, R. Dictionnaire universel de médecine, de chirurgie, de chymie, de botanique, d'anatomie, de pharmacie et d'histoire naturelle, etc., t. III. Paris, 1747.

KAWAUCHE, T. Religião e política em Rousseau: o conceito de religião civil. São Paulo: Humanitas; FAPESP, 2013.

Emílio e a medicina antiga. Educativa: Revista de Educação, v. 20, n. 1, 2017.

Medicina e educação no século XVIII: Rousseau inventor de Emílio. Educação e Filosofia, v. 32, n. 65, 2018.

METZGER, H. Attraction universelle et religion naturelle chez quelques commentateurs anglais de Newton. Paris: Hermann, 1938.

MONTESQUIEU. Do espírito das leis. São Paulo: Abril, 1973.

NEUHOUSER, F. Rousseau's Theodicy of Self-Love: Evil, Rationality, and the Drive for Recognition. Oxford University Press, 2008.

NEWTON, I. Óptica. São Paulo: Edusp, 1996.

Philosophical Writings. Ed. A. Janiak. Cambridge University Press, 2004.

PENIGAUD DE MOURGUES, T. Quelle «politique de la reconnaissance » chez Rousseau ? Une étude conceptuelle des Considérations sur le gouvernement de Pologne. Consecutio Temporum, n. 6, 2014.

Amour-propre et opinion dans Rousseau : vers une anthropologie politique de la reconnaissance. In: RENAUT, E. et al. (Org.). La Reconnaissance avant la reconnaissance : archéologie d'une problématique moderne. Lyon: ENS Éditions, 2017.

RICOEUR, P. Parcours de la reconnaissance. Trois études. Paris: Stock, 2004.

ROUSSEAU, J.-J. Discours sur les sciences et les arts ; Discours sur l'origine et les fondements de l'inégalité parmi les hommes. In: GAGNEBIN, B.; RAYMOND, M. (Dir.). Euvres complètes, t. III. Paris: Gallimard/Bibl. Pléiade, 1964a.

. Du contrat social, ou Principes du droit politique. In: GAGNEBIN, B.; RAYMOND, M. (Dir.). Cuvres complètes, t. III. Paris: Gallimard/Bibl. Pléiade, 1964b.

Émile, ou De l'Éducation. In: GAGNEBIN, B.; RAYMOND, M. (Dir.). Euvres complètes, t. IV. Paris: Gallimard/Bibl. Pléiade, 1969.

\begin{tabular}{|c|c|c|c|}
\hline Qovista Dialectus & \begin{tabular}{|l|l|} 
Ano 8 & n. 15 \\
\end{tabular} & Agosto - Dezembro 2019 & p. $328-361$ \\
\hline
\end{tabular}


Lettre à d'Alembert sur les spectacles; Essai sur l'origine des langues. In: GAGNEBIN, B.; RAYMOND, M. (Dir.). Euvres complètes, t. V. Paris: Gallimard/Bibl. Pléiade, 1995.

SALINAS FORTES, L. R. Rousseau: da teoria à prática. São Paulo: Ática, 1976.

SALOMON-BAYET, C. L'Institution de la science et l'expérience du vivant : méthode et expérience à l'Académie royale des sciences, 1666-1793. Paris: Flammarion, 2008.

SOUZA, M. G. Ocasião propícia, ocasião nefasta: tempo, história e ação política em Rousseau. Trans/Form/Ação, v. 29, n. 2, 2006.

SPECTOR, C. De Rousseau à Charles Taylor : autonomie, authenticité, reconnaissance. In: BERNARDI, B. et al. (Org.). Philosophie de Rousseau. Paris: Garnier, 2014.

STAROBINSKI, J. Jean-Jacques Rousseau : la transparence et l'obstacle. Paris: Gallimard, 1971.

As máscaras da civilização: ensaios. São Paulo: Companhia das Letras, 2001.

VARGAS, T. Trabalho e ócio: um estudo sobre a antropologia de Rousseau. São Paulo: Alameda, 2018.

VIEIRA, T. D. As noções de conhecimento útil e sua relação com a formação da autonomia de Emílio: um estudo sobre o projeto pedagógico de Rousseau. Campinas, 2017. Tese (Doutorado em Educação). Faculdade de Educação - Universidade Estadual de Campinas.

VOLTAIRE. Cartas inglesas. São Paulo: Abril, 1973 (Col. “Os Pensadores”).

\begin{tabular}{|l|l|l|l|l|}
\hline Q Rovista Dialectus & Ano 8 & n. 15 & Agosto-Dezembro 2019 & p. $328-361$ \\
\hline
\end{tabular}

